\title{
The Shadow Economy-Environmental Quality Nexus In OECD Countries: Empirical Evidence From Panel Quantile Regression
}

Lan Khanh Chu

Vietnam Banking Academy

Dung Phuong Hoang ( $\nabla$ dunghp@hvnh.edu.vn )

Vietnam Banking Academy https://orcid.org/0000-0002-0284-6953

\section{Research Article}

Keywords: ecological footprint, OECD countries, quantile regression, shadow economy

Posted Date: December 3rd, 2021

DOI: https://doi.org/10.21203/rs.3.rs-1047259/v1

License: (c) (i) This work is licensed under a Creative Commons Attribution 4.0 International License. Read Full License 


\section{Abstract}

This study explores the determinants of ecological footprint by integrating the influence of the shadow economy. The findings based on the panel quantile regression indicate that the environmental effects of the shadow economy, trade openness, energy intensity, renewable energy, and income are not homogeneous across various levels of ecological footprint. The shadow economy-ecological footprint nexus follows an inverted U-shaped pattern. Initially, the higher size of the informal economy leads to more ecosystem degradation. When the shadow economy increases to certain thresholds, its environmental impact reverts to benefit. Such threshold changes with the evolution of ecological footprint. Specifically, it first rises then decreases along with the degradation of the ecosystem. Moreover, the heterogeneous panel causality test reports the one-way directional running from the shadow economy to the ecological footprint in OECD countries. The significant and heterogeneous relationships between ecological footprint and its determining factors are also established.

\section{Introduction}

Technological progress and economic development have been believed to alleviate environmental degradation. This argument is embedded in the well-known Environmental Kuznets curve (EKC) about the inverted U-shaped relationship between income per capita and environmental pollution (Grossman and Krueger, 1991; Panayotou, 1993). In the early phase of industrialization when increasing material output is prioritized, pollution would grow along with the rise of income. However, when the economy reaches a certain income level, energy efficiency (as the outcome of the technology progress) and the rise of environmental awareness (as resulted from higher demand for well-being) would decrease pollution and ensure sustainable development. Despite the substantial empirical studies that support the EKC hypothesis (Dinda et al., 2000; Apergis and Payne, 2009; Shahbaz et al., 2012; Ahmed and Long, 2013; Ahmed et al., 2015; Javid and Sharif, 2016), there is mounting evidence that environmental pollution remains one of the tough and most salient issues, even in highincome countries.

For decades, OECD countries have taken efforts to mitigate environmental pollution through technological innovation and stringent environmental regulations and standards (OECD, 2015; OECD, 2020). Nevertheless, these well-developed economies have still been struggling with high environmental pressures. Despite stable economic development in recent years, the OECD countries have been exposed to dangerous levels of pollution and climate crisis (OECD, n.d). There are several reasons for the failure of the EKC hypothesis in the case of OECD countries. First, the EKC neglects the phenomenon of the "technical obsolescence" effect that refers to the exhaustion of the margin for successive improvements in the technological efficiency or the diminishing return of the technological advances in pollution reduction (Opschoor and Vos, 1989; Torras and Boyce, 1998). Several empirical studies report the existence of the second turning point where the pollution rises again despite the continuous increase of income. This second turning point forms the $\mathrm{N}$-shaped between economic growth and environmental pollution (Allard et al., 2018; Álvarez-Herránz et al., 2017; Caravaggio, 2020; Sinha et al., 2017). In addition, the EKC hypothesis ignores the presence of the underground sector, which may add to environmental pollution by entailing more energy use for illicit production and consumption activities (Tamazian et al., 2009). Moreover, the shadow economy may not only provide immediate goods to the formal sector but also welcome formal firms, which want to hide their polluting manufacture and cut costs when facing high environmental taxes and standards (Chaudhuri and Mukhopadhyay, 2006). This motivates us to examine the relationship between shadow economy and environmental degradation to compensate for the shortcoming of the EKC hypothesis. Moreover, by giving insights into this relationship, we could also evaluate the possibility of controlling shadow economy as an instrument to tackle environmental problems, especially when the "technical obsolescence" occurs.

The literature on the informality-environmental quality nexus has been well-established. However, there is still a lack of consensus regarding both theoretical underpinnings and empirical evidence. Theoretically, the impact of the shadow economy on environmental pollution could be explained through the mixed influences of the scale effect and the deregulation effect (Elgin and Öztunali, 2014a, 2014b; Schneider, 2015). The former refers to the ability of the shadow 
economy to slow down economic deterioration as it expands due to its small-scale and labor-intensive nature. The latter highlights the environmental risks caused by the expansion of the informal sector where there is a lack of environmental regulation. While most empirical studies affirm the deregulation effect (Abid, 2015; Baloch et at., 2021; Biswas et al., 2012; Chen et al., 2018; Imamoglu, 2018; Mazhar and Elgin, 2013), others support the scale effect (Nkengfack et al., 2019; Shao et al., 2021). On the other hand, Elgin and Öztunali (2014a, 2014b) and Yang et al. (2021) find an inverted U-shaped linkage between the two factors. The inconsistent findings among empirical studies on the environmental impacts of shadow economy motivate the emergence of another research strand that seeks to explore the moderator in such a relationship. Weak institutions, tax-hike, and stringent environmental regulation are found to intensify the deregulation effect of the shadow economy to leave more environmental burdens (Chen et al., 2018; Dauda et al., 2021; Huynh, 2020). Meanwhile, the control of corruption and expansionary fiscal policy could alleviate the detrimental impact of underground economic activities on the ecosystem (Biswas et al., 2012; Huynh, 2020). In addition, some studies argue that the level of national income could affect the direction in the informality-environmental pollution linkage, yet their findings are inconclusive (Canh et al., 2019; Sohail, 2021; Swain et al., 2020).

As the consequence of socio-economic activities, environmental degradation is a "powerful" concept which implies not only the state of ecological conditions but also the level of industrialization, the stage of social transition, and the stringency of regulation and institutions (Bowles and Park, 2005; Chen et al., 2018; Chu, 2021; Chu and Hoang, 2021; Herring and Roy, 2007; Mol and Spaargaren, 2000; York, 2007). These may, in turn, affect the extent to which the underground economic activities consume energy and the possibility that they could hide their polluting manufacturing from the government. While previous studies have been trying to explain the heterogeneity in the environmental impacts of shadow economy across countries due to the degree of the shadow economy and economic and institutional factors, there is a lack of literature about the dynamics of this relationship by the level of environmental pollution. Moreover, even though production and consumption activities are two primary sources of pollution and need to be tackled by different measures, previous studies do not separate them when examining the environmental costs of the informal sector (Abid, 2015; Baloch et at., 2021; Biswas et al., 2012; Elgin and Öztunali, 2014a, 2014b; Imamoglu, 2018; Nkengfack et al., 2019; Shao et al., 2021; Yang et al., 2021). This evokes the idea of employing the quantile regression technique to track the heterogeneity of the informalityenvironmental pollution linkage across various extents of environmental degradation while pollution from production and consumption sources are considered separately.

Based on this context, this study focuses on the non-linear relationship between shadow economy and ecological footprint as well as its heterogeneity across the distribution of ecological footprint. It is novel and exciting in three aspects. First, it contributes to the current literature about the non-linearity relationship between two key issues, shadow economy and environmental quality. To our best knowledge, no study so far has been implemented on OECD countries to estimate the environmental effect of shadow economy. This study fills this literature gap by analyzing the heterogeneous impact of shadow economy on the ecological footprint in 32 OECD countries from 1990 to 2015. The findings have important policy significance for controlling the shadow economy and protecting environmental quality. Second, this paper makes the methodological contribution by employing the panel quantile regression approaches, proposed by Canay (2011) and Powell (2016). The motivation for adopting these two approaches is that they deal effectively with the non-normality and heterogeneity of panel data. The econometric benefits of panel quantile regression allow us to provide a more comprehensive picture of the environmental effect of the shadow economy, especially in the context of countries that lie at extreme distribution. Third, our unique findings show that there is an inverted U-shaped relationship between shadow economy and ecological footprint of consumption and production. However, the empirical results indicate that the thresholds over which the impact of shadow economy changes from positive to negative vary across quantile distribution of ecological footprint. In addition, we find the existence of heterogeneity in the environmental impacts of other decisive factors such as trade openness, renewable energy, and energy intensity. The inverted or U-shaped patterns are also established in most quantiles. 
The remainder of the paper is as follows. Section 2 presents the theoretical framework and literature review. Section 3 describes the data and methodological approach. Section 4 presents the estimation results and discussions. The last section concludes and draws policy implications.

\section{Theoretical Framework And Literature Review 2.1. Theoretical framework}

\section{The scale effect and deregulation effect}

The shadow economy plays a critical role in the influence of human activities on the ecology. The literature documents both positive and negative forces in the shadow economy - environmental quality nexus. On the one hand, the shadow economy could affect the extent to which production activities release pollutants to the environment through its scale of production, also called "the scale effect" (Elgin and Öztunali, 2014a, 2014b). Specifically, since the underground economy encompasses either illegal activities or unreported income from the production of legal goods and services (Alm and Embaye, 2013), it deliberately maintains the small-scale operation to make it easier to hide from the government. Moreover, the less secure business environment also discourages informal firms to invest in a larger production scale (Morrrisson and Mead, 1996). Even when the informal firms aspirate for expansion, the lack of access to formal finance and necessary public goods and services limits their business growth (Straub, 2005). Further, as characterized by a higher labor-intensive yet lower capitalintensive production model, the shadow economy is less prone to environmental degradation, as compared to the formal sector (Antweiler et al., 2001).

On the other hand, the shadow economy intensifies the environmental burdens from production activities through its "deregulation effect" (Elgin and Öztunali, 2014a, 2014b). This effect could be observed from three primary perspectives. First, due to intrinsic features, the shadow economy itself is characterized by a lack of environmental regulation. This makes the underground activities, which are mostly unlicensed and low technology-intensive, become a major source of pollution (Schneider, 2015). Second, pressures from rigorous environmental legislation motivate the formal firms to hide their polluting manufacturing into the underground sectors for cost-cutting (Mazhar and Elgin, 2013). This may shift the pollution from the formal sectors to the shadow economy (Baksi and Bose, 2016). Third, according to the three-sector general equilibrium framework, formal firms may purchase immediate goods from their informal counterparts, which are not subject to environmental taxes and standards (Chaudhuri and Mukhopadhyay, 2006). As the underground sector grows, this further widens the gap between the actual and the allowable level of pollution. The deregulation effect of the shadow economy, therefore, reduces the effectiveness of environmental legislation even in the formal sector, and hence, contributes to more environmental degradation.

\section{The trade-related effect}

According to the theoretical framework for the trade-environment nexus proposed by Tayebi and Younespour (2012), all else equal, a capital-abundant country (normally rich nations) should produce and exchange capital-intensive goods (with high environmental impacts) for labor-intensive goods (cleaner products). Meanwhile, a labor-abundant country (the poorer nation) tends to exchange labor-intensive products for capital-intensive goods. Therefore, through international trade, the developed countries transfer the environmental burdens of their consumption to the less developed nations through the shift of polluting goods (Copeland and Taylor, 2013; Suri and Chapman, 1998).

Shadow economy, due to its intrinsic factors, could reduce barriers to international trade and hence, foster trade flows. On the one hand, the shadow economy helps exporters overcome cost barriers of international expansion (Melitz, 2003) and increase their competitiveness by paying lower wages and obtaining cheaper inputs (Zagoršek et al., 2009). On the other hand, the shadow economy increases the demand for imported goods by allowing lower prices through tax invasion. In addition, as an integral part of the shadow economy, trafficking of illegal goods contributes to both imports and exports 
(OECD, 2017). As the shadow economy fosters international trade flows, it also accelerates the transfers of trade-related pollution from the capital-abundant countries to their labor-abundant counterparts. Consequently, as the shadow economy grows, the capital-abundant nations could further reduce their net ecological footprint of trade while the labor-abundant ones suffer more environmental impacts through trade. Since this effect is rooted in the cross-border exchange of goods, in this study, it is referred to as the "trade-related effect" of informality on the environmental quality.

\subsection{Literature review and hypothesis development}

There is a growing body of literature that examines the shadow economy and environmental quality linkage. However, this relationship is found heterogeneous among different countries. Based on the MIMIC model approach with autoregressivedistributed lag (ARDL) and other co-integrating estimation techniques, Imamoglu (2018) analyzes the relationship between the size of the shadow economy and carbon dioxide emissions in Turkey over the 1970-2014 period. The study reveals that the growth of informal economic activities helps slow down the increase of environmental pollution from production. Similarly, Nkengfack et al. (2019) employ the ARDL methodology to revisit the informality-environmental quality nexus for 22 sub-Saharan Africa countries between 1991 and 2005. In line with the scale effect of the shadow economy, a higher share of the shadow economy is found to curve the emissions of carbon dioxide in both the short run and the long run, especially among the lower-middle-income countries.

In contrast, the deregulation effect of informality on the environment is found valid in many studies. In light of the Environmental Kuznets Curve hypothesis, Abid (2015) finds that similar to the formal sector, the shadow economy in Tunisia grows at the costs of the environment, as proxied by carbon dioxide emissions. This monotonically positive relationship is held for the period 1980-2009 based on a co-integrated VECM model specification. Likewise, Chen et al. (2018) examine the effects of environmental legislation and the size of shadow economy on environmental quality within 30 provinces in China between 1998 and 2012. Estimation results from the generalized method of moments (GMM) analysis show that the shadow economy deteriorates the efficacy of environmental controls, and this further increases the environmental costs of production activities (as proxied by the emissions of primary pollutants, including carbon dioxide, soot and dust, and capita wastewater). Similarly, Baloch et al. (2021) utilize the ARDL bound testing approach and panel data of Pakistan covering the 1966 -2008 period to evaluate the environmental risks resulting from the growth of shadow economy. The study affirms that underground economic activities significantly boost the level of carbon dioxide emissions from all primary sources.

Not only findings among countries are heterogeneous, but empirical evidence resulting from international data is also inconsistent. In an attempt to reach a generalized conclusion about the informality-environmental pollution nexus, Biswas et al. (2012) use fixed-effects panel regressions for more than 100 countries over the 1999-2005 period. The estimation results indicate that a higher share of the black economy is associated with a lower level of both carbon dioxide and sulphur dioxide emissions, which fits the scale effect of informality. Similarly, based on a data set of 134 nations from 1980 to 2018 , Shao et al. (2021) suggest that the shadow economy may act as an instrument to manage environmental risks from production activities. The panel data threshold regressions and co-integration techniques indicate that the shadow economy demonstrates negative linkages with gas emissions in both the short run and the long run. In contrast, Mazhar and Elgin (2013) prove the validity of the deregulation effect at the international level based on a data set of more than 100 countries between 2007 and 2010. The study reveals the mechanism underlying environmental pollution in the presence of underground economic activities. Specifically, the imposition of stringent environmental regulation in the formal sector will result in the expansion of the shadow economy that, in turn, intensifies carbon dioxide emissions.

Another strand of research has emerged to seek an explanation for the inconsistent empirical evidence of the relationship between shadow economy and pollution. Some studies contend that there could be moderators in the informalityenvironmental quality nexus. First, Biswas et al. (2012) highlight the role of corruption control in negating the deregulation effect of the informal sector on environmental pollution. This conclusion is drawn based on international evidence over the 1999-2005 period. Similarly, Dauda et al. (2021) assert that weak institutions in Africa from 1991 to 2015 could intensify the deregulation effect of the shadow economy and hence, worsen environmental impacts of informality. Second, in a study on

Page 5/29 
the environmental quality of 30 provinces in China over the 1998-2012 period, Chen et al. (2018) add that the tighter environmental regulation could further increase the unregulated emissions from the shadow economy. The stronger deregulation effect is attributed to the rise of illicit output as a response from formal polluting firms. Third, Huynh (2020) examines the role of government spending and taxation on the relationship between the black economy and air pollution in 22 Asian developing countries from 2002 to 2015. The estimation results indicate that the expansionary fiscal policy could mitigate the detrimental impact of underground economic activities on the ecological condition. In contrast, a tax hike could enhance the deregulation effect of the shadow economy on environmental degradation. Forth, the level of economic development also determines the nature of the informality-environmental quality linkage. In an empirical study of 106 countries during 1995-2012, Canh et al. (2019) find that the relationship between shadow economy and the emission of greenhouse gases, including $\mathrm{N}_{2} \mathrm{O}, \mathrm{CH}_{4}$, and $\mathrm{CO}_{2}$ is conditional on the level of national income. Specifically, the deregulation effect of the underground economy on environmental quality is dominant in high-income nations, while its scale effect is only witnessed in low and middle-income economies. In contrast, for a data set of 58 countries between 1996 and 2011 , Swain et al. (2020) reveal that a higher share of the shadow economy is associated with higher pollution in developing countries while lower environmental impacts of informality could be witnessed in developed counterparts. Contradicting the above results, the heterogeneity in the informality-environmental quality nexus is even found among countries with similar institutional quality and level of development or income. In a recent study on South Asian countries by Sohail (2021), the ARDL results indicate that the growth of the underground economy helps reduce $\mathrm{CO}_{2}$ emission in India only. Meanwhile, such a relationship is found positive in Bangladesh and Nepal yet insignificant for the remaining countries in the region.

Overall, the literature suggests that the direction of the informality-environmental quality relationship depends on the relative strength of either the scale effect or the deregulation effect against the other. This, in turn, relies largely on the economic and institutional factors that are heterogeneous across countries. We, therefore, hypothesize that:

\section{$H_{1}$ : The impact of shadow economy on environmental quality is not homogeneous across countries}

In this study, we employ the ecological footprint concept as proposed by Ree (1992) to proxy for environmental quality. This approach allows separating the estimation of the ecological footprint of production from that of consumption. Specifically, for a given nation, the ecological footprint of production is calculated based on the consumption of biocapacity originating from the national production activities. In this regard, the impact of shadow economy on the ecological footprint of production is characterized by the scale effect and the deregulation effect. Since these two effects may influence the environmental quality in opposite ways, some scholars believe that the informality-environmental quality nexus could be dynamic as the degree of informality changes. Elgin and Öztunali (2014a) find an inverted U-shaped relationship between shadow economy and carbon emissions in Turkey during 1950-2009. In more detail, a low level of carbon emissions is correlated to a small or large share of the informal sector. Meanwhile, larger levels of carbon emissions are associated with medium levels of informality. The same conclusion is reached when the authors revisit this linkage using international evidence of 152 countries from 1999 and 2009 (Elgin and Oztunali, 2014b). The non-linear nature of the informalityenvironmental quality linkage is further affirmed in empirical research in China by Yang et al. (2021). Estimation results indicate a U-inverted shaped association between the size of the informal sector and environmental pollution. As the black economy grows, the deregulation effect of informality is found dominated in raising carbon emissions before the scale effect is strong enough to demonstrate positive environmental externalities. In line with previous studies, we hypothesize that:

\section{$\mathrm{H}_{2}$ : There is a nonlinear relationship between shadow economy and ecological footprint of production}

On the other hand, the ecological footprint of consumption indicates the consumption of biocapacity by the nation's inhabitants during their consumption of either domestic or imported goods (Ree, 1992). Given that the output of the production process is either consumed domestically or exported, the ecological footprint of consumption is the sum of ecological production and net ecological footprint of trade (the difference between the ecological footprint of imports and 
that of exports). Depending on a nation's factor endowments (capital-abundant or labor-abundant), the expansion of the shadow economy would foster the cross-border exchange of whether more labor-intensive or more capital-intensive goods (Copeland and Taylor, 2013; Suri and Chapman, 1998; Tayebi and Younespour, 2012). Consequently, the shadow economy, under the trade-related effect, may influence the net ecological footprint of trade in different directions.

While previous studies on the relationship between the shadow economy and the environmental quality mostly focus on either the total emissions or the pollution from production activities only, little attention is paid to the impact of the underground sector on the environmental impacts of consumption. In a panel study on Pakistan from 1966 and 2008 , Baloch et al. (2021) examine the impact of shadow economy on CO2 emissions from both production and consumption. Despite that the study attempts to include specific sources of emissions such as solid fuel, liquid fuel, gaseous fuel consumption, electricity and heat production, transport, manufacturing industries and construction, residential buildings and commercial and public services, it fails to separate and compare the effects of underground economic activities on emission from production and that from consumption activities.

In this study, we argue that the relationship between shadow economy and the ecological footprint of consumption could be observed through not only the scale effect and the deregulation effect but also the trade-related effect. Since there are both positive and negative forces in the linkage between the size of underground economic activities and the consumption ecological footprint, there may be a change in the relative strength of one against the others by the degree of informality. This would form a non-linear relationship between shadow economy and consumption the ecological footprint.

$H_{3}$ : There is a nonlinear relationship between shadow economy and ecological footprint of consumption

\section{Data And Methodology}

\subsection{Data}

This paper focuses on the effect of shadow economy on the ecological footprint of OECD countries. Based on the data availability, 32 countries are included, i.e., Australia, Austria, Belgium, Chile, Czech Republic, Denmark, Estonia, Finland, France, Germany, Greece, Hungary, Ireland, Israel, Italy, Japan, Korea, Luxembourg, Mexico, Netherlands, New Zealand, Norway, Poland, Portugal, Slovakia, Slovenia, Spain, Sweden, Switzerland, Turkey, United Kingdom, and United States. We select the annual data covering the period from 1990 to 2015.

We use two indicators, the ecological footprint of consumption and the ecological footprint of production, taken from the Global Footprint Network to proxy for environmental quality. Both indicators are measured as global hectare per capita. The shadow economy is expressed as the proportion of informal output (of official gross domestic products). It is estimated based on the dynamic general equilibrium model-based by Elgin et al. (2021). We incorporate export and import into trade openness to capture their aggregated impacts on environmental quality. Energy usage quantifies the kg of oil equivalent per capita while renewable energy reflects the renewable proportion in total final energy consumption. Gross domestic product per capita and its square are included in the model to capture the potential of the Environmental Kuznets Curve hypothesis. The data of trade openness, energy intensity, renewable energy, and GDP per capita are obtained from the World Development Indicators database of the World Bank. Because the variables are expressed in different types of units, it is preferable to take the natural logarithm of them. This transformation also helps to facilitate the interpretation of estimation results as elasticity.

\subsection{Model and estimation method}

The present study extends the STIRPAT model of Dietz and Rosa (1994) by incorporating shadow economy to examine how this factor influences environmental quality in OECD countries. The econometric model of ecological footprint is developed as follows: 
$\operatorname{lnEF_{i,t}}=\alpha_{0}+\alpha_{1} S H A_{i, t}+\alpha_{2} S H A_{i, t}^{2}+\alpha_{3} O P E_{i, t}+\alpha_{4} E N E_{i, t}+\alpha_{5} R E N_{i, t}+$

$\alpha_{6} G D P_{i, t}+\alpha_{7} G D P_{i, t}^{2}+\varepsilon_{i, t}$

where EF represents the ecological footprint of consumption or production; SHA represents the shadow economy; OPE, ENE, REN, and GDP denotes trade openness, energy intensity, renewable energy, and GDP, respectively. Countries and time are indexed by ${ }_{i}$ and ${ }_{t}$, respectively. is the error terms. denotes the common slope coefficients to be estimated.

It is expected that the signs of shadow economy and its square are positive and negative, respectively. In other words, we hypothesize that there exists an inverted U-shaped relationship between shadow economy and environmental externalities. Considering the data have been already transformed into the natural logarithm, the level of shadow economy at the turning point will be computed by taking the exponential of the $-\alpha_{1} / 2 \alpha_{2}$. The energy intensity is believed to exert a harmful impact on environmental quality. The expected signs of coefficients of trade openness and renewable energy are either positive or negative based on the strength of their effects on consumption or production ecological footprint. The environmental impact of GDP per capita depends on the current stage of the country's economic development. Accordingly, the impact may follow a U-shaped or an inverted U-shaped pattern.

This paper resorts to the panel quantile regression to verify the heterogeneous effect of shadow economy on ecological footprint. If it is verified that the variables of interest and residuals from regressions do not follow the normality distribution, the traditional mean approaches fail to provide consistent estimated results. In contrast, the quantile regression does not rely on the normality assumption. Second, in the case that data of dependent variables contain outliers (or heavy-tailed distribution), such asymmetric feature may result in over- or under-estimation of parameters. However, the quantile regression proves effective in such an issue because its estimation process is based on the median (instead of the mean). Third, the panel quantile regression with fixed effects can mitigate the problem of unobserved individual heterogeneity and aid identification. Forth, if it is interesting to explore the policy implications based on varying impacts of the independent variable at different points in the conditional distribution of dependent variables, quantile regression is considered as an appropriate approach. Therefore, we put forward the estimation model as follows:

$$
\begin{aligned}
& Q_{E F_{i, t}}\left(\tau \mid \alpha_{i}\right)=\alpha_{i}+\alpha_{1 \tau} S H A_{i, t}+\alpha_{2 \tau} S H A_{i, t}^{2}+\alpha_{3 \tau} O P E_{i, t}+\alpha_{4 \tau} E N E_{i, t}+ \\
& \alpha_{5 \tau} R E N_{i, t}+\alpha_{6 \tau} G D P_{i, t}+\alpha_{7 \tau} G D P_{i, t}^{2}+\varepsilon_{i, t}
\end{aligned}
$$

where $Q_{\tau}$ refers to the $\tau_{\text {th }}$ conditional quantile of ecological footprint given its determining factors; $\alpha_{\tau}$ indicates the regression parameters of the $\tau_{\text {th }}$ quantile of ecological footprint.

A growing literature has developed methods to estimate equation (2), including Koenker (2004), Canay (2011), and Galvao (2011), to name a few. The main problem of such methods lies in the difficulties in estimating a large number of fixed effects $\alpha_{i}$ and considering incidental parameters problems when the time dimension is short (Powell, 2016). To overcome this issue, Powell (2016) proposes a quantile regression estimator of panel data with non-additive fixed effects. Specifically, by using within-group variation for identification purposes and maintaining the no separable disturbance property, the estimation of parameters can be inferred in the same manner as cross-sectional quantile estimates. Moreover, as the individual fixed effects are not estimated, the number of parameters to be estimated is small relative to the other panel regression techniques. Therefore, two methods by Canay (2011) and Powell (2016) are deployed to robustly estimate the environmental effects of shadow economy. To facilitate the comparison purpose, we also report the fixed effects with robust standard errors and full-modified ordinary least squares.

\section{Result And Discussion}

\subsection{Summary statistics and normality test}

Page 8/29 
The empirical results are analyzed as follows: Our analysis starts by providing a breakdown of variable summary statistics and normality test. It then shows preliminary results of cross-sectional dependence, unit root, and co-integration tests. The last and main part presents the results of panel quantile regression.

Table 1 provides the summary statistics of all variables in the natural logarithm. The means of consumption and production ecological footprint are 1.72 and 1.64, which are equivalent to 5.91 and 5.81 global hectares per capita, respectively. The average level of shadow economy is 2.75 (17.03\% of official GDP). As of the year 2015, Mexico ranks first in terms of shadow economy (6.94\%) while Switzerland ranks last (28.07\%).

Table 1

Variable statistics

\begin{tabular}{|llllll|}
\hline Variable & No. Obs & Mean & Std. Dev. & Min & Max \\
\hline EFC & 672 & 1.721 & 0.323 & 0.846 & 2.875 \\
\hline EFP & 672 & 1.642 & 0.472 & 0.739 & 2.669 \\
\hline SHA & 672 & 2.747 & 0.422 & 1.818 & 3.644 \\
\hline OPE & 672 & 4.332 & 0.534 & 2.814 & 6.012 \\
\hline ENE & 672 & 8.184 & 0.423 & 6.959 & 9.152 \\
\hline REN & 672 & 2.258 & 0.996 & -0.813 & 4.097 \\
\hline GDP & 672 & 10.205 & 0.899 & 6.133 & 11.627 \\
\hline \multicolumn{4}{l}{ Note: Variables are in natural logarithm. } \\
\hline
\end{tabular}

Figure 1 depicts that the relationship between shadow economy and ecological footprint does not follow a linear but instead a non-linear pattern. At each sub-distribution of ecological footprint, an initial increase of shadow economy leads to an escalation in ecological footprint but a further increase reduces ecological footprint. It provokes the idea that at there exists different inverted U-shaped relationships between shadow economy and ecological footprint in different sub-distributions of ecological footprint.

We check the normality of the variables, which is the basic assumption of a conditional mean regressions model, by employing the quantile-quantile plot as well as the Shapiro-Wilk and Skewness-Kurtosis test. First, the quantile-quantile plot is a visual expression of variable distribution around a diagonal line. It is demonstrated from Figure 2 that all scatter diagrams deviate from the diagonal lines. Therefore, none variable follows the normal distribution.

Second, the test by Shapiro and Wilk (1965) where the null hypothesis that a sample comes from a normally distributed population is adopted. As shown in Table 2 Panel A, the null hypothesis is rejected at a $1 \%$ significance level. The skewnesskurtosis test by Jarque and Bera (1981) in Table 2 Panel B also confirms the non-normality of the unconditional distribution of variables. Figure 3 exhibits the univariate kernel density for the residuals, which shows the strong deviation from the normal distribution. Overall, both the results of quantile-quantile plot and two residual tests imply that the panel data are not normally distributed, suggesting the implementation of panel quantile regressions.

Table 2. Shapiro-Wilk and Skewness-Kurtosis test for normality

Panel A. Shapiro-Wilk test 


\begin{tabular}{lllll} 
Variable & $\mathrm{W}$ & $\mathrm{V}$ & $\mathrm{z}$ & Prob $>\mathrm{z}$ \\
\hline EFC_residual & 0.868 & 57.988 & 9.888 & 0.000 \\
\hline EFP_residual & 0.919 & 35.596 & 8.700 & 0.000
\end{tabular}

Panel B. Skewness-Kurtosis test

\begin{tabular}{lllll} 
Variable & $\operatorname{Pr}($ Skewness $)$ & $\operatorname{Pr}($ Kurtosis) & adj chi2(2) & joint Prob>chi2 \\
\hline EFC_residual & 0.000 & 0.000 & 50.850 & 0.000 \\
\hline EFP_residual & 0.000 & 0.060 & 49.630 & 0.000
\end{tabular}

Note: The residuals are obtained from estimating equation (1) using ordinary least squares.

\subsection{Cross-sectional dependence, unit root, and co-integration tests}

This section analyzes the cross-sectional dependence test to check the suitability of the unit root and co-integration tests. Table 3 provides the results of Pesaran (2015) cross-sectional dependence test. The null hypothesis of no cross-sectional dependence is rejected at a $1 \%$ significance level for all variables. This finding calls for the adoption of second-generation unit root and co-integration tests.

Table 3

\begin{tabular}{|c|c|c|}
\hline Variable & CD test & mean $\rho$ \\
\hline$E F C$ & $27.482^{\star \star \star}$ & 0.25 \\
\hline$E F P$ & $28.961^{\star \star \star}$ & 0.27 \\
\hline$S H A$ & $66.642^{\star \star *}$ & 0.63 \\
\hline$O P E$ & $66.395^{\star \star \star}$ & 0.63 \\
\hline$E N E$ & $23.073^{\star \star \star}$ & 0.22 \\
\hline REN & $42.268^{\star \star \star}$ & 0.40 \\
\hline$G D P$ & $91.269^{\star \star \star}$ & 0.87 \\
\hline
\end{tabular}

We adopt the Pesaran (2007) panel unit root test that allows for cross-sectional dependence. The standard augmented Dickey-Fuller regressions are augmented with the cross-section averages of lagged levels and first differences of the individual variables. The results of variables in both level and first difference are reported in Table 4. It is revealed that while ecological footprint and renewable energy are stationary at a level, all variables are stationary at their first differences. Based on this finding, we can proceed for co-integration test. 


\begin{tabular}{|c|c|c|c|c|c|c|c|c|}
\hline & \multicolumn{4}{|l|}{ Level } & \multicolumn{4}{|c|}{ First difference } \\
\hline & \multicolumn{2}{|c|}{ Without trend } & \multicolumn{2}{|c|}{ With trend } & \multicolumn{2}{|c|}{ Without trend } & \multicolumn{2}{|l|}{ With trend } \\
\hline & Lags(0) & Lags(1) & Lags(0) & Lags(1) & Lags(0) & Lags(1) & Lags(0) & Lags(1) \\
\hline$E F C$ & $-2.211^{\star *}$ & 2.704 & $-3.713^{\star \star \star}$ & -0.382 & $-17.961^{\star \star \star}$ & $-8.391^{\star \star \star}$ & $-15.540^{\star \star \star}$ & $-5.426^{* \star *}$ \\
\hline$E F P$ & $-1.777^{\star \star}$ & 1.829 & $-4.517^{\star \star \star}$ & $-2.281^{\star \star}$ & $-17.087^{\star \star \star}$ & $-8.959^{\star \star \star}$ & $-14.751^{\star \star \star}$ & $-6.462^{\star \star \star}$ \\
\hline SHA & 1.574 & 1.680 & 4.651 & 4.771 & $-11.399^{\star \star \star}$ & $-1.692^{\star \star}$ & $-10.378^{\star \star \star}$ & -0.072 \\
\hline$O P E$ & 1.549 & -0.052 & 3.717 & 2.129 & $-8.403^{\star \star \star}$ & $-3.856^{\star \star \star}$ & $-6.368^{\star \star \star}$ & $-1.640^{\star}$ \\
\hline$E N E$ & 0.312 & 1.291 & $-1.900^{\star \star}$ & $-1.449^{*}$ & $-14.411^{\star \star \star}$ & $-8.741^{\star \star \star}$ & $-12.048^{\star \star \star}$ & $-6.076^{\star \star \star}$ \\
\hline REN & $-2.566^{\star \star \star}$ & -0.612 & $-5.920^{\star \star \star}$ & $-3.577^{\star \star \star}$ & $-16.907^{\star \star \star}$ & $-9.726^{\star \star \star}$ & $-13.882^{\star \star \star}$ & $-6.730^{\star \star \star}$ \\
\hline$G D P$ & 2.179 & $-1.543^{*}$ & 3.347 & -0.368 & $-5.383^{\star \star \star}$ & $-3.138^{\star \star \star}$ & $-2.287^{\star \star}$ & 0.049 \\
\hline
\end{tabular}

As the cross-sectional dependence exists, it is appropriate to employ a co-integration test that deals rigorously with its presence. This paper relies on Westerlund (2007) to verify the long-run relationship between interest variables. According to Table 5, the integration between groups $\left(G_{t}\right)$ and panels $\left(P_{t}\right)$ are confirmed at $1 \%$ significance level.

Table 5

Co-integration test

\begin{tabular}{|c|c|c|c|c|c|c|}
\hline \multirow[b]{2}{*}{ Statistic } & \multicolumn{3}{|c|}{ Consumption ecological footprint } & \multicolumn{3}{|c|}{ Production ecological footprint } \\
\hline & Value & Z-value & P-value & Value & Z-value & P-value \\
\hline$G_{t}$ & -3.045 & -3.550 & 0.000 & -10.491 & -46.563 & 0.000 \\
\hline$G_{a}$ & -5.287 & 5.662 & 1.000 & -0.744 & 9.766 & 1.000 \\
\hline$P_{t}$ & -19.494 & -6.777 & 0.000 & -17.445 & -3.721 & 0.000 \\
\hline$P_{a}$ & -9.003 & 0.226 & 0.589 & -6.212 & 3.465 & 1.000 \\
\hline
\end{tabular}

\subsection{Panel regression results}

The present study proceeds with conditional mean methods before analyzing the panel quantile regression results. Table 6 reports the estimation results of fixed effects with Driscoll and Kraay standard errors and fully modified ordinary least squares. There are several noticeable outcomes. First, although the coefficients of shadow economy and its square are positive and negative, respectively, only those obtained from production ecological footprint by fixed effects model are statistically significant. The environmental impact of trade openness is inconsistent between the two estimation methods. While the sign of trade openness coefficients is negative in the fixed effects model, they are positive in the fully modified ordinary least squares model. Similar properties are found for the relationship between economic development and ecological footprint. However, the results consistently produce the harmful effects of energy intensity and beneficial effects 
of renewable energy. Although these findings only act as references for the Canay (2011) and Powell (2016) regressions, they support the implementation of such panel quantile regressions.

Table 6

Estimation results from conditional mean methods

\begin{tabular}{|c|c|c|c|c|}
\hline & (1) & (2) & (3) & (4) \\
\hline & \multicolumn{2}{|c|}{$\begin{array}{l}\text { Fixed effects with Driscoll and Kraay standard } \\
\text { errors }\end{array}$} & \multicolumn{2}{|c|}{ Fully modified ordinary least squares } \\
\hline & $\begin{array}{l}\text { Consumption ecological } \\
\text { footprint }\end{array}$ & $\begin{array}{l}\text { Production ecological } \\
\text { footprint }\end{array}$ & $\begin{array}{l}\text { Consumption ecological } \\
\text { footprint }\end{array}$ & $\begin{array}{l}\text { Production ecological } \\
\text { footprint }\end{array}$ \\
\hline \multirow[t]{2}{*}{$S H A$} & 0.084 & $4.224^{\star \star \star}$ & 0.232 & 0.138 \\
\hline & $(0.376)$ & $(1.151)$ & $(0.957)$ & $(0.369)$ \\
\hline \multirow[t]{2}{*}{ SHA_sq } & -0.030 & $-1.012^{\star \star \star}$ & -0.047 & -0.029 \\
\hline & $(0.074)$ & $(0.276)$ & $(0.229)$ & $(0.072)$ \\
\hline \multirow[t]{2}{*}{$O P E$} & -0.087 & -0.012 & $0.127^{\star \star \star}$ & 0.072 \\
\hline & $(0.059)$ & $(0.027)$ & $(0.023)$ & $(0.049)$ \\
\hline \multirow[t]{2}{*}{ ENE } & $0.496^{\star \star \star}$ & $1.392^{\star \star \star}$ & $1.151^{\star \star \star}$ & $0.663^{\star \star \star}$ \\
\hline & $(0.110)$ & $(0.047)$ & $(0.039)$ & $(0.105)$ \\
\hline \multirow[t]{2}{*}{ REN } & $-0.054^{\star \star \star}$ & $-0.068^{\star \star \star}$ & $-0.072^{\star \star \star}$ & $-0.055^{\star \star \star}$ \\
\hline & $(0.017)$ & $(0.020)$ & $(0.017)$ & $(0.018)$ \\
\hline \multirow[t]{2}{*}{$G D P$} & 0.317 & $-27.071^{\star \star \star}$ & 0.138 & $0.701^{\star \star \star}$ \\
\hline & $(0.225)$ & $(5.478)$ & $(4.554)$ & $(0.201)$ \\
\hline \multirow[t]{2}{*}{$G D P \_s q$} & -0.011 & $1.268^{\star \star *}$ & -0.015 & $-0.042^{\star \star \star}$ \\
\hline & $(0.013)$ & $(0.256)$ & $(0.213)$ & $(0.011)$ \\
\hline \multirow[t]{2}{*}{ Constant } & $-3.922^{\star \star \star}$ & $130.085^{\star \star \star}$ & -8.381 & $-6.832^{\star \star \star}$ \\
\hline & (1.387) & $(28.490)$ & (23.685) & (1.216) \\
\hline
\end{tabular}

We use nine quantiles for a comprehensive understanding of the environmental effects of shadow economy and other decisive factors. The panel quantile regression is capable of modelling the entire conditional distribution and controls for the unobserved heterogeneity. Therefore, it facilitates the analysis at the extreme of the distribution, which is very helpful in proposing policy recommendations. The results obtained from Canay (2011) and Powell (2016) are reported in Table 7 and Table 8, respectively. In each table, we consecutively present the estimation outcome for consumption ecological footprint and production ecological footprint. At a first glance, we realize the estimation results of Canay (2011) and Powell (2016)'s methods are quite similar.

The results of quantile regression indicate that the effect of shadow economy on ecological footprint (of both consumption and production) are heterogeneous at all quantiles. The finding confirms our hypothesis $H_{1}$. Table 7 Panel A and Table 8 
Panel A show that the coefficients of shadow economy and its squares are positively and negatively significant at most quantiles (except for 10th quantile in Canay (2011) estimation). It confirms the existence of an inverted U-shaped relationship between shadow economy and ecological footprint of consumption. The finding confirms our hypothesis $\mathrm{H}_{2}$. This result is in line with Elgin and Öztunali (2014a, 2014b) and Yang et al. (2021) that claim that a higher shadow economy initially worsens environmental quality but to a certain threshold, it helps control environmental degradation. The non-linear association between the underground sector and the ecological footprint of production may be due to the change in the relative strength of the deregulation effect over the scale effect and vice versa by the degree of informality. Initially, the existence of a small-scale shadow economy could not create enough positive environmental externalities to offset the environmental costs of its deregulation effect. Only when the size of the shadow economy reaches a sufficiently high level, the scale effect of underground activities prevails to save energy consumption and creates a significant reduction in ecological footprint of production.

Table 7. Canay (2011) estimation results

Panel A. Consumption ecological footprint

\begin{tabular}{|c|c|c|c|c|c|c|c|c|c|}
\hline & 10th & 20th & 30th & 40th & 50th & 60th & 70th & 80th & 90th \\
\hline \multirow[t]{2}{*}{ SHA } & 0.195 & $0.454^{\star \star}$ & $0.517^{\star \star \star}$ & $0.627^{\star \star \star}$ & $1.081^{\star \star \star}$ & $1.105^{\star \star \star}$ & $1.344^{\star \star \star}$ & $1.234^{\star \star \star}$ & $1.369^{\star \star \star}$ \\
\hline & $(0.203)$ & $(0.221)$ & (0.196) & $(0.206)$ & $(0.220)$ & $(0.212)$ & $(0.223)$ & $(0.254)$ & $(0.215)$ \\
\hline \multirow[t]{2}{*}{$S H A \_s q$} & -0.035 & $-0.077^{*}$ & $-0.085^{\star *}$ & $-0.101^{\star \star \star}$ & $-0.187^{\star \star \star}$ & $-0.195^{\star \star \star}$ & $-0.235^{\star \star *}$ & $-0.220^{\star \star \star}$ & $-0.248^{\star \star \star}$ \\
\hline & $(0.039)$ & $(0.041)$ & $(0.036)$ & $(0.038)$ & (0.039) & $(0.037)$ & $(0.038)$ & $(0.045)$ & $(0.041)$ \\
\hline \multirow[t]{2}{*}{$O P E$} & $0.057^{\star \star \star}$ & $0.039^{\star \star \star}$ & $0.029^{\star \star \star}$ & $0.032^{*}$ & 0.000 & $-0.032^{* *}$ & $-0.036^{* *}$ & $-0.024^{* \star}$ & $-0.046^{\star \star *}$ \\
\hline & $(0.011)$ & (0.009) & $(0.011)$ & $(0.017)$ & $(0.017)$ & $(0.014)$ & $(0.016)$ & $(0.010)$ & $(0.016)$ \\
\hline \multirow[t]{2}{*}{ ENE } & $0.461^{\star \star \star}$ & $0.418^{\star \star \star}$ & $0.412^{\star \star \star}$ & $0.420^{\star \star \star}$ & $0.444^{\star \star \star}$ & $0.479^{\star \star \star}$ & $0.493^{\star \star \star}$ & $0.456^{\star \star \star}$ & $0.383^{\star \star \star}$ \\
\hline & $(0.028)$ & $(0.025)$ & $(0.023)$ & $(0.031)$ & $(0.030)$ & $(0.025)$ & $(0.024)$ & $(0.017)$ & $(0.021)$ \\
\hline \multirow[t]{2}{*}{ REN } & $-0.042^{\star \star \star}$ & $-0.037^{\star \star \star}$ & $-0.029^{\star \star \star}$ & $-0.027^{\star \star \star}$ & $-0.028^{\star \star \star}$ & $-0.021^{\star \star \star}$ & -0.014 & $-0.045^{\star \star \star}$ & $-0.073^{\star \star \star}$ \\
\hline & $(0.005)$ & $(0.005)$ & $(0.006)$ & $(0.010)$ & $(0.010)$ & $(0.008)$ & (0.009) & $(0.007)$ & $(0.010)$ \\
\hline \multirow[t]{2}{*}{$G D P$} & $-0.476^{\star \star \star}$ & $-0.767^{\star \star \star}$ & $-0.939^{\star \star \star}$ & $-0.972^{\star \star \star}$ & $-1.050^{\star \star \star}$ & $-1.177^{\star \star \star}$ & $-1.361^{\star \star \star}$ & $-1.808^{\star \star \star}$ & $-2.050^{\star \star \star}$ \\
\hline & $(0.169)$ & $(0.217)$ & $(0.079)$ & $(0.147)$ & $(0.165)$ & $(0.184)$ & $(0.224)$ & (0.099) & $(0.064)$ \\
\hline \multirow[t]{2}{*}{$G D P \_s q$} & $0.030^{\star \star \star}$ & $0.045^{\star \star \star}$ & $0.053^{\star \star \star}$ & $0.056^{\star \star \star}$ & $0.059^{\star \star \star}$ & $0.065^{\star \star \star}$ & $0.076^{\star \star \star}$ & $0.100^{\star \star \star}$ & $0.114^{\star \star \star}$ \\
\hline & $(0.008)$ & $(0.011)$ & $(0.004)$ & (0.008) & $(0.009)$ & (0.009) & $(0.012)$ & $(0.006)$ & $(0.004)$ \\
\hline \multirow[t]{2}{*}{ Constant } & -0.930 & 0.554 & $1.409^{\star \star \star}$ & $1.301^{*}$ & 1.130 & $1.638^{*}$ & $1.996^{*}$ & $4.595^{\star \star \star}$ & $6.227^{\star \star \star}$ \\
\hline & $(0.896)$ & (1.073) & $(0.438)$ & $(0.720)$ & $(0.789)$ & $(0.862)$ & (1.071) & $(0.565)$ & $(0.401)$ \\
\hline No. Obs & 672 & 672 & 672 & 672 & 672 & 672 & 672 & 672 & 672 \\
\hline $\mathrm{dSHA} / \mathrm{dEFC}$ & & 19.069 & 20.930 & 22.286 & 18.000 & 17.002 & 17.454 & 16.520 & 15.801 \\
\hline
\end{tabular}

Panel B. Production ecological footprint 


\begin{tabular}{|c|c|c|c|c|c|c|c|c|c|}
\hline & 10th & 20th & 30th & 40th & 50th & 60th & 70th & 80th & 90th \\
\hline \multirow[t]{2}{*}{$S H A$} & $1.553^{\star \star \star}$ & $0.831^{\star *}$ & $1.898^{\star \star \star}$ & $2.246^{\star \star \star}$ & $2.483^{\star \star \star}$ & $3.557^{\star \star \star}$ & $3.375^{\star \star \star}$ & $4.152^{\star \star \star}$ & $4.083^{\star \star \star}$ \\
\hline & (0.178) & $(0.373)$ & $(0.241)$ & $(0.222)$ & $(0.292)$ & $(0.430)$ & $(0.485)$ & $(0.668)$ & $(0.374)$ \\
\hline \multirow[t]{2}{*}{ SHA_sq } & $-0.299^{\star \star \star}$ & $-0.161^{\star \star}$ & $-0.354^{\star \star \star}$ & $-0.414^{\star \star \star}$ & $-0.448^{\star \star \star}$ & $-0.648^{\star \star \star}$ & $-0.614^{\star \star \star}$ & $-0.765^{\star \star \star}$ & $-0.823^{\star \star \star}$ \\
\hline & $(0.033)$ & $(0.065)$ & $(0.044)$ & $(0.040)$ & $(0.054)$ & $(0.079)$ & $(0.089)$ & $(0.120)$ & $(0.068)$ \\
\hline \multirow[t]{2}{*}{$O P E$} & $-0.037^{\star \star \star}$ & $-0.097^{\star \star \star}$ & $-0.129^{\star \star \star}$ & $-0.127^{\star \star \star}$ & $-0.126^{\star \star *}$ & $-0.161^{\star \star \star}$ & $-0.154^{\star \star \star}$ & $-0.187^{\star \star \star}$ & $-0.279^{\star \star \star}$ \\
\hline & $(0.011)$ & $(0.020)$ & $(0.013)$ & $(0.013)$ & $(0.018)$ & $(0.024)$ & $(0.029)$ & $(0.040)$ & $(0.022)$ \\
\hline \multirow[t]{2}{*}{$E N E$} & $0.933^{\star \star \star}$ & $1.154^{\star \star \star}$ & $1.063^{\star \star \star}$ & $1.036^{\star \star \star}$ & $1.028^{\star \star \star}$ & $0.910^{\star \star \star}$ & $0.882^{\star \star \star}$ & $0.765^{\star \star \star}$ & $0.732^{\star \star \star}$ \\
\hline & $(0.020)$ & $(0.051)$ & $(0.030)$ & $(0.022)$ & $(0.037)$ & $(0.046)$ & $(0.049)$ & $(0.061)$ & $(0.040)$ \\
\hline \multirow[t]{2}{*}{ REN } & $0.093^{\star \star \star}$ & $0.138^{\star \star \star}$ & $0.143^{\star \star \star}$ & $0.152^{\star \star \star}$ & $0.167^{\star \star \star}$ & $0.158^{\star \star \star}$ & $0.165^{\star \star \star}$ & $0.109^{\star \star \star}$ & $0.071^{\star \star \star}$ \\
\hline & $(0.008)$ & $(0.012)$ & $(0.011)$ & $(0.007)$ & $(0.010)$ & $(0.013)$ & $(0.015)$ & $(0.022)$ & $(0.011)$ \\
\hline \multirow[t]{2}{*}{$G D P$} & $0.402^{\star \star \star}$ & $0.765^{\star \star \star}$ & $0.365^{\star \star \star}$ & 0.185 & 0.043 & -0.311 & $-0.518^{\star \star}$ & $-0.902^{\star \star \star}$ & $-0.627^{\star \star \star}$ \\
\hline & $(0.081)$ & $(0.107)$ & $(0.111)$ & $(0.115)$ & $(0.136)$ & $(0.216)$ & $(0.222)$ & $(0.159)$ & $(0.232)$ \\
\hline \multirow[t]{2}{*}{$G D P \_s q$} & $-0.033^{\star \star \star}$ & $-0.053^{\star \star \star}$ & $-0.030^{\star \star \star}$ & $-0.019^{\star \star \star}$ & -0.010 & 0.011 & $0.022^{*}$ & $0.044^{\star \star \star}$ & $0.026^{* *}$ \\
\hline & $(0.005)$ & $(0.006)$ & $(0.006)$ & $(0.006)$ & $(0.008)$ & $(0.012)$ & $(0.012)$ & $(0.009)$ & $(0.013)$ \\
\hline \multirow[t]{2}{*}{ Constant } & $-8.902^{\star \star \star}$ & $-11.148^{\star \star \star}$ & $-10.040^{\star \star \star}$ & $-9.594^{\star \star \star}$ & $-9.413^{* * *}$ & $-8.153^{\star \star \star}$ & $-6.710^{\star \star \star}$ & $-4.797^{\star \star \star}$ & $-4.158^{\star \star \star}$ \\
\hline & $(0.354)$ & $(0.651)$ & $(0.646)$ & $(0.631)$ & $(0.768)$ & $(1.161)$ & (1.188) & (1.086) & (1.337) \\
\hline No. Obs & 672 & 672 & 672 & 672 & 672 & 672 & 672 & 672 & 672 \\
\hline $\mathrm{dSHA} / \mathrm{dEFC}$ & 13.423 & 13.207 & 14.597 & 15.068 & 15.978 & 15.558 & 15.617 & 15.085 & 11.948 \\
\hline
\end{tabular}

On the other hand, as the sum of ecological footprint of production and net ecological footprint of trade, the inverted $U$ shaped relationship between shadow economy and ecological footprint of consumption could be explained through the interactions among the scale effect, deregulation effect, and trade-related effect of informality. Our estimation results indicate that trade openness causes environmental deterioration in countries with low and medium levels of ecological footprint, whereas higher trade activities improve environmental quality in more environmentally degraded countries (see below). Given that the growth of the shadow economy helps foster cross-border exchange (OECD, 2017; Zagoršek et al., 2009), the trade-related effect of informality on consumption ecological footprint is positive (support the deregulation effect) in countries with better environmental quality yet negative (enhance the scale effect) where is characterized by poorer ecological conditions. However, the findings regarding the inverted U-shaped relationship between informality and both the ecological footprint of production and that of consumption indicate that the trade-related effect, either positive or negative, is not strong enough to offset the difference between the deregulation effect and the scale effect to create significant differences between the two indicators. Based on Canay (2011) estimation, the threshold equals $19.07 \%$ at the $20^{\text {th }}$ quantile, increasing to $22.29 \%$ at the $40^{\text {th }}$ percentile then decreasing gradually to $15.80 \%$ at the $90^{\text {th }}$ quantile. The corresponding turning points obtained from Powell (2016) are 19.47\%, 22.26\%, and 15.99\%. This may be because at low and medium levels of ecological footprint, both trade-related and deregulation effects increase ecological footprint as the shadow economy expands. Meanwhile, in countries with a higher level of environmental deterioration, the trade-effect supports the 
scale effect to alleviate the overall ecological footprint. Consequently, a higher level of scale effect is required to offset the negative impacts of shadow economy in countries with lower levels of ecological footprint.

For the year ended 2015, most countries with the lower level of environmental quality in terms of consumption ecological footprint (than other countries in our sample), e.g. Luxembourg, United States, Denmark, and Australia, have relatively low levels of shadow economy. By further controlling the informal sector, they can obtain a better environmental quality. In contrast, countries with higher levels of environmental quality, e.g. Mexico, Turkey, Hungary, Spain, Portugal, are facing the expansion of the informal sector. These countries need double efforts to reduce shadow economy considerably to fall behind the turning point. Only at the low levels of shadow economy (lower than those of more environmentally degraded countries), they can attain the environmental benefit of controlling the informal sector.

With regard to other explanatory variables, we also find the existence of heterogeneity. First, although energy intensity causes environmental degradation at all quantiles (Salman et al., 2019; Xie et al., 2021), its impacts varied significantly. Notably, the impact follows an $\mathrm{N}$-shaped pattern where it reaches the high level at the $10^{\text {th }}$ and $70^{\text {th }}$ quantile.

Second, renewable energy has a beneficial impact on the consumption ecological footprint. This result is in line with those of Anwar et al. (2021), Chen and Lei (2018), Cheng et al. (2021), Khan et al. (2020), and Gyamfi et al. (2021). The highest benefit is observed at the extreme high quantiles.

Third, we find two contrasting effects of international trade on consumption ecological footprint. For the low to the medium distribution of ecological footprint, higher trade activities with foreign partners significantly degrade environmental quality. However, higher international trade helps improve the situation in countries with a high level of environmental deprivation. The heterogeneous impact of trade openness on environmental quality across countries is mentioned in both theoretical framework and empirical evidence. From the consumption perspective, Tayebi and Younespour (2012) contend that the direction of the trade-environmental quality nexus depends on the factor endowment of a country. Capital-abundant nations tend to obtain environmental benefits from trade by exporting more capital-intensive goods (with high environmental impacts) and importing more labor-intensive goods (cleaner products). In contrast, labor-abundant countries may bear environmental costs from trade by exchanging labor-intensive goods for capital-intensive products. From the production perspective, trade openness facilitates investment and production activities, and hence, increases energy demand and degrades the environment (Cole, 2006; Shahbaz et al., 2013; Koengkan et al., 2018). Previous studies provide empirical evidence about the harmful impacts of trade openness (Asici and Acar, 2016; Demiral et al., 2021; Shahbaz et al., 2020) or beneficial (Qi et al., 2019). Others affirm both the positive and negative forces of higher trade activities on the ecological conditions across nations (Chen and Lei, 2018; Wang et al., 2018; Zhu et al., 2016). Due to the heterogeneity of factor endowments and production capacities among OECD countries, these two contrasting roles of trade openness could be witnessed in this study. The higher level of the ecological footprint may imply a higher level of industrialization that leaves more environmental costs while awarding more accumulation of capital. Correspondingly, countries with more environmental degradation (as compared to others in our sample) are more likely capital-abundant agents that obtain environmental benefits from international trade.

Last, the relationship between economic development and environmental degradation follows a U-shaped pattern as the coefficients of GDP and its squares are negatively and positively significant. This outcome is inconsistent with the EKC hypothesis (Grossman and Krueger, 1991; Panayotou, 1993) and empirical findings of previous research (Anwar et al., 2021; Cheng et al., 2021; Salman et al., 2019; Zhang et al., 2016) that recommends an inverted U-shaped relationship between the two factors. Instead, our findings fit the U-shaped part of the N-shaped association in the economic growth - environmental deterioration nexus, as found in Sinha et al. (2017), Álvarez-Herránz et al. (2017), Allard et al. (2018), and Caravaggio (2020). In this study, our sample covers OECD countries since 1990. From that time, their economic growth may reach a sufficiently high level where the technical effect dominates the scale effect to create a significant positive contribution to environmental quality right at the early phase. Meanwhile, the increase of ecological footprint, as witnessed in the latter stage, could be due to the "technical obsolescence" effect that happens when the margin for successive improvements in the technological

Page $15 / 29$ 
efficiency is exhausted or there is a diminishing return of the technological advances in reducing pollution (Opschoor and Vos, 1989; Torras and Boyce, 1998). The threshold of GDP per capita where the environmental impact of higher income changes from beneficial to harmful increases with degradation level of environmental quality. More specifically, the turning point increases when the ecological footprint increases among OECD countries. In other words, the threshold of GDP per capita where the "technical obsolescence" could be witnessed is lower in countries with less economic degradation. Therefore, it is alerted that the continuous enhancement of environmental quality may signal the coming exhaustion of technical efficiency in reducing the ecological footprint. Therefore, other measures should be taken to save the environment. In contrast, more efforts for technical progress in countries with a high level of environmental deprivation could be still rewarded with improved ecological conditions. It is noteworthy that as of the year 2015, all countries in our sample have income per capita higher than the turning points at all quantiles. This finding provides vigorous support for the dominant and harmful scale effect of economic development on environmental quality in OECD countries.

Table 7 Panel B and Table 8 Panel B present the estimation results for production ecological footprint, which are somewhat different from those for consumption ecological footprint. First, although an inverted U-shape still captures the linkage between shadow economy and ecological footprint of production, the threshold is lower than the threshold of ecological footprint of consumption at all quantiles. The finding confirms our hypothesis $\mathrm{H}_{3}$. It means that for production ecological footprint, shadow economy only needs to increase by a lower level to obtain its beneficial effects. This may be because while the ecological footprint of both production and consumption are influenced by the deregulation effect and the scale effect, the consumption ecological footprint is additionally affected by the trade-related effect (originating from exportimport activities). Our findings indicate that, in general, the trade-related effect would fuel the deregulation effect, which dampens the ecological footprint of consumption. Consequently, the size of shadow economy needs to expand up to a higher threshold to dominate both the deregulation effect and the trade-related effect and create significant improvement in environmental quality. In this regard, the net ecological footprint of trade of OECD countries is mostly positive.

Table 8. Powell (2016) estimation results

Panel A. Consumption ecological footprint 


\begin{tabular}{|c|c|c|c|c|c|c|c|c|c|}
\hline & 10th & 20th & 30th & 40th & 50th & 60th & 70th & 80th & 90th \\
\hline \multirow[t]{2}{*}{ SHA } & $0.124^{*}$ & $0.380^{\star \star \star}$ & $0.521^{\star \star \star}$ & $0.695^{\star \star \star}$ & $0.990^{\star * \star}$ & $1.154^{\star \star \star}$ & $1.333^{\star \star \star}$ & $1.377^{\star \star \star}$ & $1.375^{\star \star \star}$ \\
\hline & $(0.072)$ & $(0.088)$ & $(0.102)$ & $(0.156)$ & $(0.153)$ & $(0.168)$ & (0.133) & $(0.106)$ & $(0.100)$ \\
\hline \multirow[t]{2}{*}{ SHA_sq } & $-0.024^{*}$ & $-0.064^{\star \star \star}$ & $-0.088^{\star \star \star}$ & $-0.112^{\star \star \star}$ & $-0.168^{\star \star \star}$ & $-0.202^{\star \star \star}$ & $-0.233^{\star \star \star}$ & $-0.245^{\star \star \star}$ & $-0.248^{\star \star \star}$ \\
\hline & $(0.013)$ & $(0.016)$ & $(0.020)$ & $(0.027)$ & $(0.028)$ & $(0.030)$ & $(0.024)$ & (0.018) & $(0.018)$ \\
\hline \multirow[t]{2}{*}{$O P E$} & $0.048^{\star \star \star}$ & $0.042^{\star \star \star}$ & $0.047^{\star \star \star}$ & $0.028^{\star *}$ & 0.005 & $-0.031^{\star \star \star}$ & $-0.028^{\star *}$ & $-0.018^{\star \star \star}$ & $-0.045^{\star \star \star}$ \\
\hline & $(0.007)$ & $(0.005)$ & $(0.013)$ & $(0.012)$ & $(0.017)$ & $(0.010)$ & $(0.012)$ & $(0.005)$ & $(0.004)$ \\
\hline \multirow[t]{2}{*}{$E N E$} & $0.457^{\star \star \star}$ & $0.436^{\star \star \star}$ & $0.443^{\star \star \star}$ & $0.402^{\star \star \star}$ & $0.436^{\star \star \star}$ & $0.462^{\star \star \star}$ & $0.476^{\star \star \star}$ & $0.446^{\star \star \star}$ & $0.385^{\star \star \star}$ \\
\hline & $(0.013)$ & $(0.018)$ & $(0.025)$ & $(0.028)$ & $(0.027)$ & $(0.037)$ & $(0.031)$ & $(0.028)$ & $(0.020)$ \\
\hline \multirow[t]{2}{*}{ REN } & $-0.045^{\star \star \star}$ & $-0.035^{\star \star \star}$ & $-0.026^{\star \star \star}$ & $-0.031^{\star \star \star}$ & $-0.028^{\star \star \star}$ & $-0.021^{\star \star \star}$ & $-0.019^{\star \star \star}$ & $-0.045^{\star \star \star}$ & $-0.071^{\star \star \star}$ \\
\hline & $(0.003)$ & $(0.003)$ & $(0.004)$ & $(0.005)$ & $(0.007)$ & $(0.006)$ & $(0.007)$ & $(0.006)$ & $(0.005)$ \\
\hline \multirow[t]{2}{*}{$G D P$} & $-0.494^{\star \star \star}$ & $-0.691^{\star \star \star}$ & $-0.549^{*}$ & $-1.176^{\star \star \star}$ & $-1.137^{\star \star \star}$ & $-1.318^{\star \star \star}$ & $-1.464^{\star \star \star}$ & $-1.790^{\star \star \star}$ & $-2.059^{\star \star \star}$ \\
\hline & $(0.058)$ & $(0.135)$ & $(0.293)$ & $(0.269)$ & $(0.233)$ & $(0.369)$ & $(0.287)$ & $(0.096)$ & $(0.064)$ \\
\hline \multirow[t]{2}{*}{$G D P \_s q$} & $0.031^{\star \star \star}$ & $0.041^{\star \star \star}$ & $0.032^{\star \star}$ & $0.067^{\star \star \star}$ & $0.064^{\star \star \star}$ & $0.073^{\star \star \star}$ & $0.082^{\star \star \star}$ & $0.099^{\star \star \star}$ & $0.115^{\star \star \star}$ \\
\hline & $(0.003)$ & $(0.007)$ & $(0.016)$ & $(0.015)$ & $(0.013)$ & $(0.020)$ & $(0.016)$ & $(0.005)$ & $(0.003)$ \\
\hline \multirow[t]{2}{*}{ Constant } & $-0.628^{\star \star}$ & 0.175 & -0.685 & $2.301^{*}$ & 1.652 & 2.312 & $2.589^{*}$ & $4.342^{\star \star \star}$ & $6.223^{\star \star \star}$ \\
\hline & $(0.302)$ & $(0.727)$ & $(1.596)$ & (1.372) & $(1.262)$ & (1.918) & (1.487) & $(0.764)$ & $(0.563)$ \\
\hline No. Obs & 672 & 672 & 672 & 672 & 672 & 672 & 672 & 672 & 672 \\
\hline dSHA/dEFP & 13.423 & 13.207 & 14.597 & 15.068 & 15.978 & 15.558 & 15.617 & 15.085 & 11.948 \\
\hline
\end{tabular}

Panel B. Production ecological footprint 


\begin{tabular}{|c|c|c|c|c|c|c|c|c|c|}
\hline & 10th & 20th & 30th & 40th & 50th & 60 th & 70th & 80th & 90th \\
\hline \multirow[t]{2}{*}{$S H A$} & $1.524^{\star \star \star}$ & $0.747^{\star \star \star}$ & $1.734^{\star \star \star}$ & $2.309^{\star \star \star}$ & $2.540^{\star \star \star}$ & $3.411^{\star \star \star}$ & $3.508^{\star \star \star}$ & $4.150^{\star \star \star}$ & $3.938^{\star \star \star}$ \\
\hline & $(0.045)$ & $(0.255)$ & $(0.234)$ & $(0.168)$ & $(0.288)$ & $(0.164)$ & $(0.303)$ & $(0.231)$ & $(0.172)$ \\
\hline \multirow[t]{2}{*}{ SHA_sq } & $-0.294^{\star \star \star}$ & $-0.146^{\star \star \star}$ & $-0.327^{\star \star \star}$ & $-0.425^{\star \star \star}$ & $-0.464^{\star \star \star}$ & $-0.621^{\star \star \star}$ & $-0.640^{\star \star \star}$ & $-0.773^{\star \star \star}$ & $-0.796^{\star \star \star}$ \\
\hline & $(0.008)$ & $(0.049)$ & $(0.043)$ & $(0.031)$ & $(0.054)$ & $(0.030)$ & $(0.055)$ & $(0.036)$ & $(0.031)$ \\
\hline \multirow[t]{2}{*}{$O P E$} & $-0.039^{\star \star \star}$ & $-0.087^{\star \star \star}$ & $-0.133^{\star \star \star}$ & $-0.123^{\star \star \star}$ & $-0.131^{\star \star \star}$ & $-0.160^{\star \star \star}$ & $-0.151^{\star \star \star}$ & $-0.213^{\star \star \star}$ & $-0.278^{\star \star \star}$ \\
\hline & $(0.003)$ & $(0.011)$ & $(0.013)$ & $(0.008)$ & $(0.015)$ & $(0.013)$ & $(0.011)$ & $(0.032)$ & $(0.007)$ \\
\hline \multirow[t]{2}{*}{$E N E$} & $0.926^{\star \star \star}$ & $1.186^{\star \star \star}$ & $0.996^{\star \star \star}$ & $1.089^{\star \star \star}$ & $0.981^{\star \star \star}$ & $0.918^{\star \star \star}$ & $0.882^{\star \star \star}$ & $0.740^{\star \star \star}$ & $0.732^{\star \star \star}$ \\
\hline & $(0.003)$ & $(0.065)$ & $(0.059)$ & $(0.054)$ & $(0.060)$ & $(0.021)$ & $(0.031)$ & $(0.033)$ & $(0.015)$ \\
\hline \multirow[t]{2}{*}{ REN } & $0.091^{\star \star \star}$ & $0.147^{\star \star \star}$ & $0.128^{\star \star \star}$ & $0.161^{\star \star \star}$ & $0.156^{\star \star \star}$ & $0.159^{\star \star \star}$ & $0.160^{\star \star \star}$ & $0.100^{\star \star \star}$ & $0.074^{\star \star \star}$ \\
\hline & $(0.002)$ & $(0.017)$ & $(0.013)$ & $(0.009)$ & $(0.015)$ & $(0.005)$ & $(0.007)$ & $(0.012)$ & $(0.005)$ \\
\hline \multirow[t]{2}{*}{$G D P$} & $0.371^{\star \star \star}$ & $0.930^{\star \star \star}$ & -0.114 & 0.486 & -0.194 & $-0.331^{\star \star \star}$ & $-0.400^{\star \star}$ & $-1.048^{\star \star \star}$ & $-0.654^{\star \star \star}$ \\
\hline & $(0.025)$ & $(0.291)$ & $(0.423)$ & $(0.333)$ & $(0.318)$ & $(0.119)$ & $(0.182)$ & $(0.215)$ & $(0.076)$ \\
\hline \multirow[t]{2}{*}{ GDP_sq } & $-0.032^{\star \star \star}$ & $-0.062^{\star \star \star}$ & -0.003 & $-0.036^{*}$ & 0.003 & $0.011^{*}$ & 0.016 & $0.052^{\star \star \star}$ & $0.028^{\star \star \star}$ \\
\hline & $(0.001)$ & $(0.016)$ & $(0.023)$ & $(0.018)$ & $(0.017)$ & $(0.006)$ & $(0.010)$ & $(0.012)$ & $(0.004)$ \\
\hline \multirow[t]{2}{*}{ Constant } & $-8.641^{\star \star \star}$ & $-12.098^{\star \star \star}$ & $-7.101^{\star \star \star}$ & $-11.481^{\star \star \star}$ & $-7.895^{\star * \star}$ & $-7.884^{\star \star \star}$ & $-7.420^{\star \star \star}$ & $-3.707^{\star \star}$ & $-3.867^{\star * *}$ \\
\hline & $(0.114)$ & (1.683) & $(2.593)$ & $(2.090)$ & $(2.114)$ & $(0.747)$ & $(1.322)$ & (1.686) & $(0.450)$ \\
\hline No. Obs & 672 & 672 & 672 & 672 & 672 & 672 & 672 & 672 & 672 \\
\hline dSHA/dEFP & 13.241 & 19.468 & 19.302 & 22.257 & 19.038 & 17.399 & 17.471 & 16.613 & 15.993 \\
\hline
\end{tabular}

Second, higher energy intensity is detrimental to the quality of the ecosystem. The magnitude of the environmental effect of energy intensity reaches the highest level at the $20^{\text {th }}$ quantile before declining along with the degradation of environmental quality. It means that in countries with ruined eco-system, energy intensity is not the main culprit but other factors.

Third, it is interesting to find that the coefficients of renewable energy are positive at all quantiles. In fact, a modern energy structure fails to lessen environmental damage but aggravates it through the rebound effect. Specifically, the shift to more renewable energy consumption may lower the market price of some other polluting energy sources and thus, raises demand for that resources among manufacturers (Yang and Li, 2017). This would end up with higher total energy consumption along the whole supply chain. Moreover, the exploitation and application of renewable energy may require the construction of new infrastructure systems (Font Vivanco et al., 2014) and the inputs of other "brown" capital goods (with more harmful effects on the environment) (Jenkins et al., 2011; Rosenbaum, 2019).

Forth, international trade helps to reduce the ecological footprint of production, though the magnitude of the effect escalates with the degradation of ecological quality. This may be because the production sector benefits from the trade-related R\&D spillover effects when joining the global value chains (Runge, 1994; Helpman, 1998). In more detail, international trade flows of eco-products could accelerate the diffusion of green technologies (Bi et al., 2015; Costantini and Crespi, 2008; Franco and Marin, 2015; Jiang and Liu, 2015; Tarancón and del Río, 2007) and better management methods (Bakhsh et al., 2017; Haider 
Zaidi et al., 2019) for lowering energy use and enhancing environmental quality. Moreover, trade openness also fosters the international expansion of the supply chains that, in turn, facilitates the transfer of polluting capital goods and dirty industry (producing pollution-intensive goods), especially from developed countries to the developing economies (Suri and Chapman, 1998; Copeland and Taylor, 2013). Our findings are backed by previous empirical research that supports the positive contribution of higher trade activities on the ecological conditions, such as Chen and Lei (2018), Wang et al. (2018), and Zhu et al., 2016).

Last, at low quantiles, the relationship between production activities and ecological footprint follows an inverted U-shaped pattern. At high quantiles, this pattern is reverted to be a U-shaped form.

To sum up, we find several distinct heterogeneities existing in the roles of shadow economy and many decisive factors with different quality of the environment. These findings reinforce our adoption of panel quantile regression and explain the reason for the inconsistent and insignificant effects of explanatory variables on ecological footprints found in conditional mean regressions. Figure 4 further illustrates our arguments. 
Table 9

The Dumitrescu and Hurlin (2012) causality test

\begin{tabular}{|c|c|c|c|c|c|}
\hline Null hypothesis & $\bar{Z}$ statistics & Causality flow & Null hypothesis & $\bar{Z}$ statistics & Causality flow \\
\hline 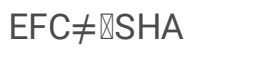 & -0.4516 & \multirow[t]{2}{*}{$\mathrm{EFC} \leftarrow \mathrm{SHA}$} & $\mathrm{SHA} \neq \llbracket \mathrm{OPE}$ & $3.2878^{\star \star \star}$ & \multirow[t]{2}{*}{$\mathrm{SHA} \leftrightarrow \mathrm{OPE}$} \\
\hline 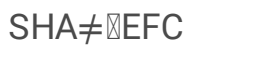 & $5.0781^{\star \star \star}$ & & 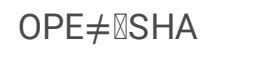 & $2.7259^{\star \star \star}$ & \\
\hline $\mathrm{EFC} \neq \bowtie \mathrm{OPE}$ & 0.8579 & \multirow[t]{2}{*}{$\mathrm{EFC} \leftarrow \mathrm{OPE}$} & $\mathrm{SHA} \neq \llbracket \mathrm{ENE}$ & $7.9222^{\star \star \star}$ & \multirow[t]{2}{*}{$\mathrm{SHA} \rightarrow \mathrm{ENE}$} \\
\hline $\mathrm{OPE} \neq \mathbb{E} \mathrm{EFC}$ & $8.9166^{\star \star \star}$ & & $\mathrm{ENE} \neq \mathbb{\mathrm { S } H \mathrm { A }}$ & 1.3594 & \\
\hline $\mathrm{EFC} \neq \otimes \mathrm{ENE}$ & $5.5741^{\star \star \star}$ & \multirow[t]{2}{*}{$\mathrm{EFC} \leftrightarrow \mathrm{ENE}$} & $S H A \neq \triangle R E N$ & $5.8481^{\star \star \star}$ & \multirow[t]{2}{*}{$\mathrm{SHA} \leftrightarrow \mathrm{REN}$} \\
\hline $\mathrm{ENE} \neq \otimes \mathrm{EFC}$ & $4.9772^{\star \star \star}$ & & 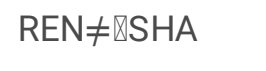 & $3.2331^{\star \star \star}$ & \\
\hline $\mathrm{EFC} \neq \otimes \mathrm{REN}$ & $3.3895^{\star \star \star}$ & \multirow[t]{2}{*}{$\mathrm{EFC} \leftrightarrow \mathrm{REN}$} & $\mathrm{SHA} \neq \mathbb{G} \mathrm{GP}$ & $2.8668^{\star \star \star}$ & \multirow[t]{2}{*}{$\mathrm{SHA} \leftrightarrow \mathrm{GDP}$} \\
\hline $\mathrm{REN} \neq \otimes \mathrm{EFC}$ & $7.6612^{\star \star \star}$ & & 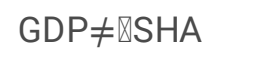 & $5.9993^{\star \star \star}$ & \\
\hline $\mathrm{EFC} \neq \llbracket \mathrm{GDP}$ & 0.8389 & \multirow[t]{2}{*}{$\mathrm{EFC} \leftarrow \mathrm{GDP}$} & $\mathrm{OPE} \neq \mathbb{E} \mathrm{ENE}$ & $10.4726^{\star * *}$ & \multirow[t]{2}{*}{$\mathrm{OPE} \rightarrow \mathrm{ENE}$} \\
\hline 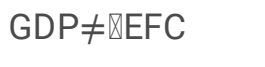 & $5.9782^{\star \star \star}$ & & $\mathrm{ENE} \neq \llbracket \mathrm{OPE}$ & 0.2982 & \\
\hline 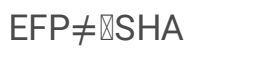 & 1.2161 & \multirow[t]{2}{*}{$\mathrm{EFP} \leftarrow \mathrm{SHA}$} & 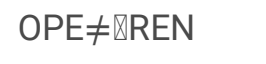 & $2.2877^{\star \star}$ & \multirow[t]{2}{*}{ OPE $\leftrightarrow$ REN } \\
\hline$S H A \neq \otimes E F P$ & $7.7784^{\star \star \star}$ & & $\mathrm{REN} \neq \square \mathrm{OPE}$ & $4.2078^{\star \star \star}$ & \\
\hline $\mathrm{EFP} \neq \llbracket \mathrm{OPE}$ & $1.7120^{*}$ & \multirow[t]{2}{*}{$\mathrm{EFP} \leftrightarrow \mathrm{OPE}$} & $\mathrm{OPE} \neq \llbracket \mathrm{GDP}$ & $1.9027^{*}$ & \multirow[t]{2}{*}{$\mathrm{OPE} \leftrightarrow \mathrm{GDP}$} \\
\hline $\mathrm{OPE} \neq \otimes \mathrm{EFP}$ & $10.0714^{\star \star \star}$ & & $\mathrm{GDP} \neq \llbracket \mathrm{OPE}$ & $2.4962^{* *}$ & \\
\hline $\mathrm{EFP} \neq \otimes \mathrm{ENE}$ & $7.8205^{\star \star \star}$ & \multirow[t]{2}{*}{$\mathrm{EFP} \leftrightarrow \mathrm{ENE}$} & $\mathrm{ENE} \neq \llbracket \mathrm{REN}$ & $5.5762^{\star \star \star}$ & \multirow[t]{2}{*}{$\mathrm{ENE} \leftrightarrow \mathrm{REN}$} \\
\hline 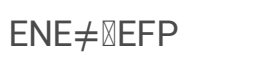 & $2.5746^{\star \star \star}$ & & 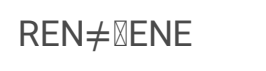 & $15.0223^{* \star *}$ & \\
\hline $\mathrm{EFP} \neq \otimes \mathrm{REN}$ & $2.9393^{\star \star \star}$ & \multirow[t]{2}{*}{$\mathrm{EFP} \leftrightarrow \mathrm{REN}$} & $\mathrm{ENE} \neq \llbracket \mathrm{GDP}$ & $1.7496^{*}$ & \multirow[t]{2}{*}{$\mathrm{ENE} \leftrightarrow \mathrm{GDP}$} \\
\hline $\mathrm{REN} \neq \mathbb{E} \mathrm{EFP}$ & $13.6311^{\star * *}$ & & $\mathrm{GDP} \neq \llbracket \mathrm{ENE}$ & $9.3060^{\star \star \star}$ & \\
\hline $\mathrm{EFP} \neq \llbracket \mathrm{GDP}$ & 0.8956 & \multirow[t]{2}{*}{$\mathrm{EFP} \leftarrow \mathrm{GDP}$} & $\mathrm{REN} \neq \llbracket \mathrm{GDP}$ & 1.2006 & \multirow[t]{2}{*}{$\mathrm{REN} \leftarrow \mathrm{GDP}$} \\
\hline 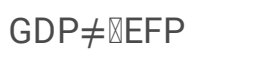 & $7.3235^{\star \star \star}$ & & $\mathrm{GDP} \neq \otimes \mathrm{REN}$ & $8.2011^{\star \star *}$ & \\
\hline
\end{tabular}

This paper also adopts Dumitrescu and Hurlin (2012) test to assess the Granger causal relationship between interested variables. Table 9 presents the results on a pairwise basis. We find uni-directional associations running from shadow economy to ecological footprint and energy intensity. It implies that the shadow economy can exert its influence on environmental quality directly and indirectly through energy usage. Another one-way relationship exists involving income per capita and ecological footprint. In contrast, ecological footprint, and energy intensity, renewable energy have bi-directional causal linkages. It is noticeable that while the effect from trade openness to consumption ecological footprint is one-way directional, it is a two-way directional effect in the case of production ecological footprint. This result infers that the production activities in OECD countries are more sensitive to environmental changes than the consumption activities, which may be resulted from the environmental regulations, for example. Shadow economy and trade openness, renewable energy, 
and income per capita have two-way effects. Overall, the causal interaction of shadow economy to all the variables proves that shadow economy is an important factor to consider in abating environmental degradation.

\section{Conclusion And Policy Implications}

This study explores the determinants of ecological footprint by integrating the influence of shadow economy. It is motivated by the important size of shadow economy as well as the varied level of environmental quality in OCED countries. In addition, there is a lack of previous attempts to examine the non-linear relationship between shadow economy and ecological footprint in this high-income country group. By employing quantile regression for panel data of 32 OECD countries from 1990 to 2015, the findings show that the environmental effects of shadow economy, trade openness, energy intensity, renewable energy, and income are not homogeneous across ecological footprint levels. The shadow economy and ecological footprint nexus follow an inverted U-shape. Initially, the higher size of the informal economy leads to more ecosystem degradation. When the shadow economy increases to certain thresholds, the environmental impact reverts to benefit. Such threshold changes with the state of ecological footprint. Specifically, it first rises then decreases along with the degradation of the ecosystem. The significant relationships between ecological footprint and its determining factors are also established. While higher energy intensity causes harm to the ecosystem with unequal influence degrees, the environmental impact of international trade varies between harmful and beneficial ways. Although trade openness is found to lessen environmental degradation in most quantiles, it leads to more degradation in countries with a less ecological footprint of consumption. Renewable energy proves effective in reducing consumption ecological footprint but exacerbates the environmental deprivation in terms of production ecological footprint due to the rebound effect. The U-shaped relationship between income and ecological footprint is found in most quantiles, which emphasizes the scale effect of economic development on environmental quality.

The empirical findings of this study are helpful to the policymakers and future researchers because it provides both theoretical and empirical foundation for the relatively new era of environmental quality's determinants, the informal activities. Reducing shadow economy and controlling environmental quality are two complementary actions due to their interactive relationship. In fact, the effectiveness of environmental policies for any country depends on the size of informal sector because a high proportion of unregulated activities will significantly reduce the scope and efficacy of regulations. Our findings indicate that most countries with lower levels of environmental quality, e.g. Luxembourg, the United States, Denmark, and Australia, have a relatively low level of shadow economy. By further controlling the informal sector, better environmental quality is achieved. However, it is not an easy task for the government because the informal sector always accounts for a certain proportion of the whole economy. In contrast, countries with higher levels of environmental quality, e.g. Mexico, Turkey, Hungary, Spain, Portugal, are facing the expansion of the informal sector. These countries need double efforts to reduce shadow economy considerably to fall behind the turning point. They can attain the environmental benefit of controlling the informal sector only at the significantly lower levels of the informal sector. Therefore, formalization of the informal sector is a pre-condition for (or at least to be implemented along with) the implementation of stringent environmental regulation in OECD countries. At the end of the day, countries at all levels of environmental quality should prioritize measures that reduce the proportion of shadow economy to achieve better environmental quality.

Simply preventing the shadow economy from spreading or reducing it to a lower proportion without solving the fundamental causes is far more than enough. A variety of coherent and comprehensive measures should be taken because individual policy intervention in isolation has only limited effectiveness. Better and more accessible education and training are essential to help workers move into better-paid formal jobs. This measure should be implemented along with the political and fiscal reforms, which facilitate the transition from the informal to the formal sector. The policymakers also need to expand the small and start-up firms' access to market and finance to foster their productivity and growth. In addition, it is required to safeguard people who are in the transition process from informal to formal sector because of their inherent vulnerabilities. The social security system and the government's ability to intervene to support vulnerable groups should be upgraded to ensure an enhanced safety net.

Page 21/29 
Again, given the inter-relationship between informal activities and environmental quality, the above-mentioned actions should be introduced together with environmental protection policies. The government should enforce more stringent environmental regulations as well as provide incentives for the research, development, and demonstration of green technologies. It is noted that the contribution of such regulations to environmental preservation depends greatly on the implementation of relevant regulations and follow-up supervision. Finally, yet importantly, efforts should be made to further cultivate environmental awareness and to improve the business sense of rights and responsibilities.

Future research can be carried out using other variables that affect the role of shadow economies on environmental quality, including institutional quality, knowledge sophistication, fiscal policies, to name a few. The scope of this research framework can be extended for other country groups or any individual country if relevant data exist.

\section{Declarations}

Ethics approval and consent to participate: Not applicable

Consent for publication: Not applicable

Availability of data and materials: All data analysed during this study are available and freely collected from public sources.

Competing interests: The authors declare that they have no competing interests

Funding: No funding

Authors' contributions: Conceptualization: Lan Khanh Chu; Methodology: Lan Khanh Chu; Formal analysis and investigation: Lan Khanh Chu, Dung Phuong Hoang; Writing - original draft preparation: Dung Phuong Hoang; Writing - review and editing: Lan Khanh Chu; Supervision: Lan Khanh Chu

\section{References}

1. Abid M (2015) The close relationship between informal economic growth and carbon emissions in Tunisia since 1980: The (ir)relevance of structural breaks. Sustainable Cities and Society 15:11-21. https://doi.org/10.1016/j.scs.2014.11.001

2. Ahmed K, Long W (2012) Environmental Kuznets Curve and Pakistan: An Empirical Analysis. Procedia Economics and Finance 1:4-13. https://doi.org/10.1016/S2212-5671(12)00003-2

3. Ahmed K, Long W (2013) An empirical analysis of CO 2 emission in Pakistan using EKC hypothesis. Journal of International Trade Law and Policy 12(2):188-200. https://doi.org/10.1108/JITLP-10-2012-0015

4. Allard A, Takman J, Uddin GS, Ahmed A (2018) The N-shaped environmental Kuznets curve: an empirical evaluation using a panel quantile regression approach. Environ Sci Pollut Res 25(6):5848-5861. https://doi.org/10.1007/s11356017-0907-0

5. Alm J, Embaye A (2013) Using Dynamic Panel Methods to Estimate Shadow Economies Around the World, 1984-2006. Public Financ Rev 41(5):510-543. https://doi.org/10.1177/1091142113482353

6. Álvarez-Herránz A, Balsalobre D, Cantos JM, Shahbaz M (2017) Energy Innovations-GHG Emissions Nexus: Fresh Empirical Evidence from OECD Countries. Energy Policy 101:90-100. https://doi.org/10.1016/j.enpol.2016.11.030

7. Antweiler W, Copeland BR, Taylor MS (2001) Is Free Trade Good for the Environment? Am Econ Rev 91(4):877-908. https://doi.org/10.1257/aer.91.4.877

8. Anwar A, Siddique M, Eyup Dogan, Sharif A (2021) The moderating role of renewable and non-renewable energy in environment-income nexus for ASEAN countries: Evidence from Method of Moments Quantile Regression. Renewable Energy 164:956-967. https://doi.org/10.1016/j.renene.2020.09.128

Page $22 / 29$ 
9. Apergis N, Payne JE (2009) Energy consumption and economic growth in Central America: Evidence from a panel cointegration and error correction model. Energy Econ 31(2):211-216. https://doi.org/10.1016/j.eneco.2008.09.002

10. Bakhsh K, Rose S, Ali MF, Ahmad N, Shahbaz M (2017) Economic growth, CO 2 emissions, renewable waste and FDI relation in Pakistan: New evidences from 3SLS. J Environ Manage 196:627-632.

https://doi.org/10.1016/j.jenvman.2017.03.029

11. Baksi S, Bose P (2016) Informal sector, regulatory compliance, and leakage. J Dev Econ 121:166-176. https://doi.org/10.1016/j.jdeveco.2016.03.008

12. Bali Swain R, Kambhampati US, Karimu A (2020) Regulation, governance and the role of the informal sector in influencing environmental quality? Ecol Econ 173:106649. https://doi.org/10.1016/j.ecolecon.2020.106649

13. Baloch A, Shah SZ, Rasheed S, Rasheed B (2021) The impact of shadow economy on environmental degradation: empirical evidence from Pakistan. GeoJournal. https://doi.org/10.1007/s10708-020-10354-6

14. Bera AK, Jarque CM (1981) Efficient tests for normality, homoscedasticity and serial independence of regression residuals. Econ Lett 7(4):313-318. https://doi.org/10.1016/0165-1765(81)90035-5

15. Bi K, Huang P, Ye H (2015) Risk identification, evaluation and response of low-carbon technological innovation under the global value chain: A case of the Chinese manufacturing industry. Technol Forecast Soc Chang 100:238-248. https://doi.org/10.1016/j.techfore.2015.07.005

16. Biswas AK, Farzanegan MR, Thum M (2012) Pollution, shadow economy and corruption: Theory and evidence. Ecol Econ 75:114-125. https://doi.org/10.1016/j.ecolecon.2012.01.007

17. Bowles S, Park Y (2005) Emulation, Inequality, and Work Hours: Was Thorsten Veblen Right? Econ J 115(507):F397F412. https://doi.org/10.1111/j.1468-0297.2005.01042.x

18. Busenitz LW, Gómez C, Spencer JW (2000) Country Institutional Profiles: Unlocking Entrepreneurial Phenomena. Acad Manag J 43(5):994-1003. https://doi.org/10.5465/1556423

19. Canay IA (2011) A simple approach to quantile regression for panel data. The Econometrics Journal 14(3):368-386. https://doi.org/10.1111/j.1368-423X.2011.00349.x

20. Canh NP, Thanh SD, Schinckus C, Bensemann J, Thanh LT (2019) GLOBAL EMISSIONS: A NEW CONTRIBUTION FROM THE SHADOW ECONOMY. International Journal of Energy Economics and Policy 9(3):320-337. https://doi.org/10.32479/ijeep.7244

21. Caravaggio N (2020) A global empirical re-assessment of the Environmental Kuznets curve for deforestation. Forest Policy and Economics 119:102282. https://doi.org/10.1016/j.forpol.2020.102282

22. Chaudhuri S, Mukhopadhyay U (2006) Pollution and Informal Sector: A Theoretical Analysis. J Econ Integr 21(2):363378. https://doi.org/10.11130/jei.2006.21.2.363

23. Chen H, Hao Y, Li J, Song X (2018) The impact of environmental regulation, shadow economy, and corruption on environmental quality: Theory and empirical evidence from China. J Clean Prod 195:200-214.

https://doi.org/10.1016/j.jclepro.2018.05.206

24. Chen W, Lei Y (2018) The impacts of renewable energy and technological innovation on environment-energy-growth nexus: New evidence from a panel quantile regression. Renewable Energy 123:1-14. https://doi.org/10.1016/j.renene.2018.02.026

25. Cheng C, Ren X, Dong K, Dong X, Wang Z (2021) How does technological innovation mitigate CO2 emissions in OECD countries? Heterogeneous analysis using panel quantile regression. J Environ Manage 280:111818. https://doi.org/10.1016/j.jenvman.2020.111818

26. Chu LK (2021) Economic structure and environmental Kuznets curve hypothesis: new evidence from economic complexity. Appl Econ Lett 28(7):612-616. https://doi.org/10.1080/13504851.2020.1767280

27. Chu LK, Hoang DP (2020) How does economic complexity influence income inequality? New evidence from international data. Econ Anal Policy 68:44-57. https://doi.org/10.1016/j.eap.2020.08.004

Page 23/29 
28. Chu LK, Hoang DP (2021) The complementarity of income equalization and innovation for more effective emission reduction. J Environ Manage 284:112007. https://doi.org/10.1016/j.jenvman.2021.112007

29. Cole MA (2006) Does trade liberalization increase national energy use? Econ Lett 92(1):108-112. https://doi.org/10.1016/j.econlet.2006.01.018

30. Copeland BR, Taylor MS (2013) Trade and the Environment: Theory and Evidence. Princeton University Press, Princeton

31. Costantini V, Crespi F (2008) Environmental regulation and the export dynamics of energy technologies. Ecol Econ 66(2-3):447-460. https://doi.org/10.1016/j.ecolecon.2007.10.008

32. Dada JT, Ajide FM (2021) The moderating role of institutional quality in shadow economy-pollution nexus in Nigeria. Management of Environmental Quality: An International Journal 32(3):506-523. https://doi.org/10.1108/MEQ-10-20200238

33. Demiral M, Akça EE, Tekin I (2021) Predictors of global carbon dioxide emissions: Do stringent environmental policies matter? Environ Dev Sustain. https://doi.org/10.1007/s10668-021-01444-7

34. Dinda S (2004) Environmental Kuznets Curve Hypothesis: A Survey. Ecol Econ 49(4):431-455. https://doi.org/10.1016/j.ecolecon.2004.02.011

35. Dumitrescu E-I, Hurlin C (2012) Testing for Granger non-causality in heterogeneous panels. Econ Model 29(4):14501460. https://doi.org/10.1016/j.econmod.2012.02.014

36. Elgin C, Öztunali O (2014a) Pollution and informal economy. Econ Syst 38(3):333-349. https://doi.org/10.1016/j.ecosys.2013.11.002

37. Elgin C, Öztunali O (2014b) Environmental Kuznets Curve for the Informal Sector of Turkey (1950-2009). Panoeconomicus 61(4):471-485. https://doi.org/10.2298/PAN1404471E

38. Elgin C, Kose MA, Ohnsorge F, Yu S (2021) Chapter 2: Understanding the Informal Economy: Concepts and Trends. In The Long Shadow of Informality: Challenges and Policies, edited by Ohnsorge, F. and Yu., S. Washington, DC: World Bank

39. Font Vivanco D, Kemp R, van der Voet E, Heijungs R (2014) Using LCA-based Decomposition Analysis to Study the Multidimensional Contribution of Technological Innovation to Environmental Pressures. J Ind Ecol 18(3):380-392. https://doi.org/10.1111/jiec.12118

40. Franco C, Marin G (2017) The Effect of Within-Sector, Upstream and Downstream Environmental Taxes on Innovation and Productivity. Environmental and Resource Economics 66(2):261-291. https://doi.org/10.1007/s10640-015-9948-3

41. Galvao AF (2011) Quantile regression for dynamic panel data with fixed effects. J Econ 164(1):142-157. https://doi.org/10.1016/j.jeconom.2011.02.016

42. Grossman GM, Krueger AB (1991) Environmental impacts of a North American free trade agreement.National Bureau of Economic Research No.3914. http://www.nber.org/papers/w3914.pdf

43. Gyamfi BA, Adedoyin FF, Bein MA, Bekun FV, Agozie DQ (2021) The anthropogenic consequences of energy consumption in E7 economies: Juxtaposing roles of renewable, coal, nuclear, oil and gas energy: Evidence from panel quantile method. J Clean Prod 295:126373. https://doi.org/10.1016/j.jclepro.2021.126373

44. Haider Zaidi SA, Zafar MW, Shahbaz M, Hou F (2019) Dynamic linkages between globalization, financial development and carbon emissions: Evidence from Asia Pacific Economic Cooperation countries. J Clean Prod 228:533-543. https://doi.org/10.1016/j.jclepro.2019.04.210

45. Helpman E (1998) Explaining the structure of foreign trade: Where do we stand? Review of World Economy 134(4):573589. https://doi.org/10.1007/bf02773288

46. Herring H, Roy R (2007) Technological innovation, energy efficient design and the rebound effect. Technovation 27(4):194-203. https://doi.org/10.1016/j.technovation.2006.11.004

47. Huynh CM (2020) Shadow economy and air pollution in developing Asia: what is the role of fiscal policy? Environmental Economics and Policy Studies 22(3):357-381. https://doi.org/10.1007/s10018-019-00260-8 
48. Imamoglu $\mathrm{H}$ (2018) Is the informal economic activity a determinant of environmental quality? Environ Sci Pollut Res 25(29):29078-29088. https://doi.org/10.1007/s11356-018-2925-y

49. Javid M, Sharif F (2016) Environmental Kuznets curve and financial development in Pakistan. Renew Sustain Energy Rev 54:406-414. https://doi.org/10.1016/j.rser.2015.10.019

50. Jenkins J, Nordhaus T, Shellenberger M (2011) Energy Emergence: Rebound and Backfire as Emergent Phenomena. Breakthrough Institute, USA

51. Jiang X, Liu Y (2015) Global value chain, trade and carbon: Case of information and communication technology manufacturing sector. Energy Sustain Dev 25:1-7. https://doi.org/10.1016/j.esd.2014.12.001

52. Khan H, Khan I, Binh TT (2020) The heterogeneity of renewable energy consumption, carbon emission and financial development in the globe: A panel quantile regression approach. Energy Reports 6:859-867. https://doi.org/10.1016/j.egyr.2020.04.002

53. Koenker R (2004) Quantile regression for longitudinal data. Journal of Multivariate Analysis 91(1):74-89. https://doi.org/10.1016/j.jmva.2004.05.006

54. Mazhar U, Elgin C (2013) Environmental regulation, pollution and the informal economy. SBP Research Bulletin 9:62-81

55. Mead DC, Morrisson C (1996) The informal sector elephant. World Dev 24(10):1611-1619. https://doi.org/10.1016/0305-750X(96)00065-4

56. Melitz MJ (2003) The Impact of Trade on Intra-Industry Reallocations and Aggregate Industry Productivity. Econometrica 71(6):1695-1725. https://doi.org/10.1111/1468-0262.00467

57. Mol APJ, Spaargaren G (2000) Ecological modernisation theory in debate: A review. Environmental Politics 9(1):17-49. https://doi.org/10.1080/09644010008414511

58. Nkengfack H, Fotio K, Totouom A (2020) How Does the Shadow Economy Affect Environmental Quality in Sub-Saharan Africa? Evidence from Heterogeneous Panel Estimations. Journal of the Knowledge Economy. https://doi.org/10.1007/s13132-020-00685-7

59. OECD (2001) OECD Environmental Strategy for the First Decade of the 21 st Century. http://www.oecd.org/dataoecd/33/40/1863539.pdf

60. OECD (2015) Aligning Policies for a Low-carbon Economy. OECD. https://doi.org/10.1787/9789264233294-en

61. OECD (2017) Shining Light on the Shadow Economy:Opportunities and Threats. https://www.oecd.org/tax/crime/shining-light-on-the-shadow-economy-opportunities-and-threats.pdf

62. OECD (2020) How's Life? 2020. OECD Publishing, Paris. https://doi.org/10.1787/9870c393-en

63. OECD. (n.d.). OECD environmental data and indicators. https://www.oecd.org/env/indicators-modelling-outlooks/dataand-indicators.htm

64. Opschoor JB, Vos H (1989) Economic Instruments for Environmental Protection. Organization for Economic Cooperation and Development, Paris, France

65. Panayotou T (1993) Empirical Tests and Policy Analysis of Environmental Degradation at Different Stages of Economic Development, Working Paper WP238 Technology and Employment Programme, Geneva: International Labor Office

66. Pesaran $\mathrm{MH}$ (2007) A simple panel unit root test in the presence of cross-section dependence. J Appl Econom 22(2):265-312. https://doi.org/10.1002/jae.951

67. Pesaran MH (2015) Testing Weak Cross-Sectional Dependence in Large Panels. Econom Rev 34(6-10):1089-1117. https://doi.org/10.1080/07474938.2014.956623

68. Powell D (2016) Quantile regression with nonadditive fixed effects

69. Qi S, Peng H, Zhang X, Tan X (2019) Is energy efficiency of Belt and Road Initiative countries catching up or falling behind? Evidence from a panel quantile regression approach. Appl Energy 253:113581.

https://doi.org/10.1016/j.apenergy.2019.113581

Page 25/29 
70. Rosenbaum E (2019) Rebound effects and green growth - An examination of their relationship in a parsimonious equilibrium input-output-framework. J Clean Prod 225:121-132. https://doi.org/10.1016/j.jclepro.2019.03.296

71. Runge CF (1994) Freer trade, protected environment. Council on Foreign Relations Press, New York

72. Salman M, Long X, Dauda L, Mensah CN, Muhammad S (2019) Different impacts of export and import on carbon emissions across 7 ASEAN countries: A panel quantile regression approach. Sci Total Environ 686:1019-1029. https://doi.org/10.1016/j.scitotenv.2019.06.019

73. Schneider F (2015) Size and Development of the Shadow Economy of 31 European and 5 Other OECD Countries from 2003 to 2014: Different Developments? Journal of Self-Governance and Management Economics 3(4):7-29

74. Shahbaz M, Lean HH, Shabbir MS (2012) Environmental Kuznets Curve hypothesis in Pakistan: Cointegration and Granger causality. Renew Sustain Energy Rev 16(5):2947-2953. https://doi.org/10.1016/j.rser.2012.02.015

75. Shahbaz M, Raghutla C, Chittedi KR, Jiao Z, Vo XV (2020) The effect of renewable energy consumption on economic growth: Evidence from the renewable energy country attractive index. Energy 207:118162.

https://doi.org/10.1016/j.energy.2020.118162

76. Shahbaz M, Shahzad SJH, Mahalik MK, Hammoudeh S (2018) Does Globalisation Worsen Environmental Quality in Developed Economies? Environmental Modeling \& Assessment 23(2):141-156. https://doi.org/10.1007/s10666-0179574-2

77. Shao J, Tillaguango B, Alvarado R, Ochoa-Moreno S, Alvarado-Espejo J (2021) Environmental Impact of the Shadow Economy, Globalisation, Trade and Market Size: Evidence Using Linear and Non-Linear Methods. Sustainability 13(12):6539. https://doi.org/10.3390/su13126539

78. SHAPIRO SS, WILK MB (1965) An analysis of variance test for normality (complete samples). Biometrika 52(3-4):591611. https://doi.org/10.1093/biomet/52.3-4.591

79. Sohail MT, Ullah S, Majeed MT, Usman A, Andlib Z (2021) The shadow economy in South Asia: dynamic effects on clean energy consumption and environmental pollution. Environ Sci Pollut Res 28(23):29265-29275. https://doi.org/10.1007/s11356-021-12690-7

80. Straub S (2005) Informal sector: The credit market channel. J Dev Econ 78(2):299-321. https://doi.org/10.1016/j.jdeveco.2004.09.005

81. Suri V, Chapman D (1998) Economic growth, trade and energy: implications for the environmental Kuznets curve. Ecol Econ 25(2):195-208. https://doi.org/10.1016/S0921-8009(97)00180-8

82. Tamazian A, Chousa JP, Vadlamannati KC (2009) Does higher economic and financial development lead to environmental degradation: Evidence from BRIC countries. Energy Policy 37(1):246-253.

https://doi.org/10.1016/j.enpol.2008.08.025

83. Tayebi SK, Younespour S (2012) The effect of trade openness on environmental quality: Evidence from Iran's trade relations with the selected countries of the different blocks. Iranian Economic Review 16(32):19-40. https://doi.org/10.22059/IER.2012.32736

84. Torras M, Boyce JK (1998) Income, inequality, and pollution: a reassessment of the environmental Kuznets Curve. Ecol Econ 25(2):147-160. https://doi.org/10.1016/S0921-8009(97)00177-8

85. Wang N, Zhu H, Guo Y, Peng C (2018) The heterogeneous effect of democracy, political globalization, and urbanization on PM2.5 concentrations in G20 countries: Evidence from panel quantile regression. J Clean Prod 194:54-68. https://doi.org/10.1016/j.jclepro.2018.05.092

86. Westerlund J (2007) Testing for Error Correction in Panel Data. Oxf Bull Econ Stat 69(6):709-748. https://doi.org/10.1111/j.1468-0084.2007.00477.x

87. Xie Z, Wu R, Wang S (2021) How technological progress affects the carbon emission efficiency? Evidence from national panel quantile regression. J Clean Prod 307:127133. https://doi.org/10.1016/j.jclepro.2021.127133 
88. Yang L, Li Z (2017) Technology advance and the carbon dioxide emission in China - Empirical research based on the rebound effect. Energy Policy 101:150-161. https://doi.org/10.1016/j.enpol.2016.11.020

89. Yang J, Tan Y, Xue D, Huang G, Xing Z (2021) The Environmental Impacts of Informal Economies in China: Inverted Ushaped Relationship and Regional Variances. Chin Geogra Sci 31(4):585-599. https://doi.org/10.1007/s11769-0211210-z

90. York R (2007) Demographic trends and energy consumption in European Union Nations, 1960-2025. Soc Sci Res 36(3):855-872. https://doi.org/10.1016/j.ssresearch.2006.06.007

91. Zagoršek H, Jaklič M, Hribernik A (2009) The Shadow Economy and Its Impact on National Competitiveness: The Case of Slovenia. South East European Journal of Economics and Business 4(1). https://doi.org/10.2478/v10033-009-00036

92. Zhang Y-J, Jin Y-L, Chevallier J, Shen B (2016) The effect of corruption on carbon dioxide emissions in APEC countries: A panel quantile regression analysis. Technol Forecast Soc Chang 112:220-227.

https://doi.org/10.1016/j.techfore.2016.05.027

93. Zhu H, Duan L, Guo Y, Yu K (2016) The effects of FDI, economic growth and energy consumption on carbon emissions in ASEAN-5: Evidence from panel quantile regression. Econ Model 58:237-248.

https://doi.org/10.1016/j.econmod.2016.05.003

\section{Figures}

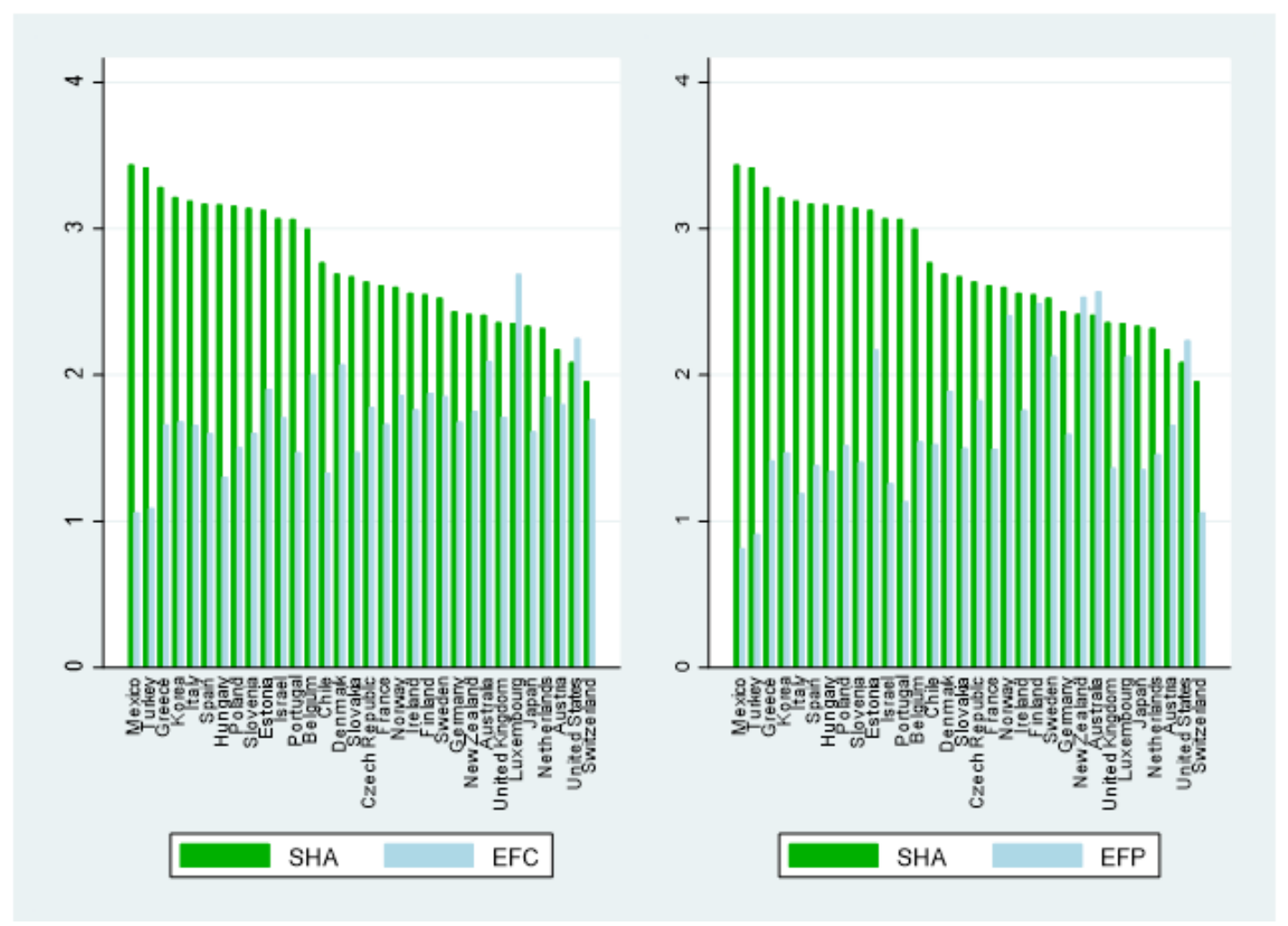

Figure 1

Shadow economy, ecological footprint of consumption and production Note: Variables are in natural logarithm. The bar chart expresses the mean of shadow economy, ecological footprint of consumption and production of each country over the period 1990-2015. 

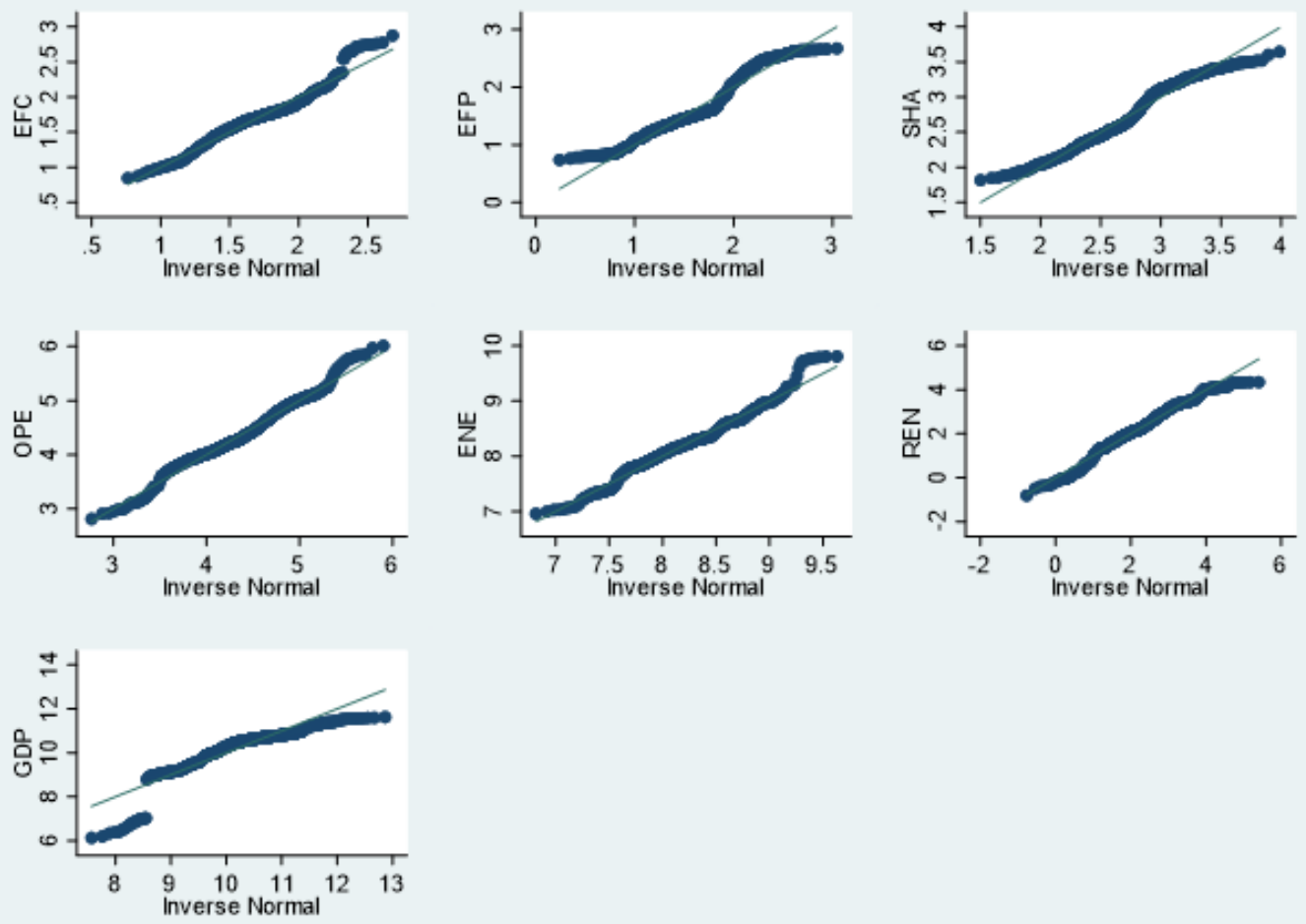

\section{Figure 2}

Quantile-quantile plot Note: Variables are in natural logarithm

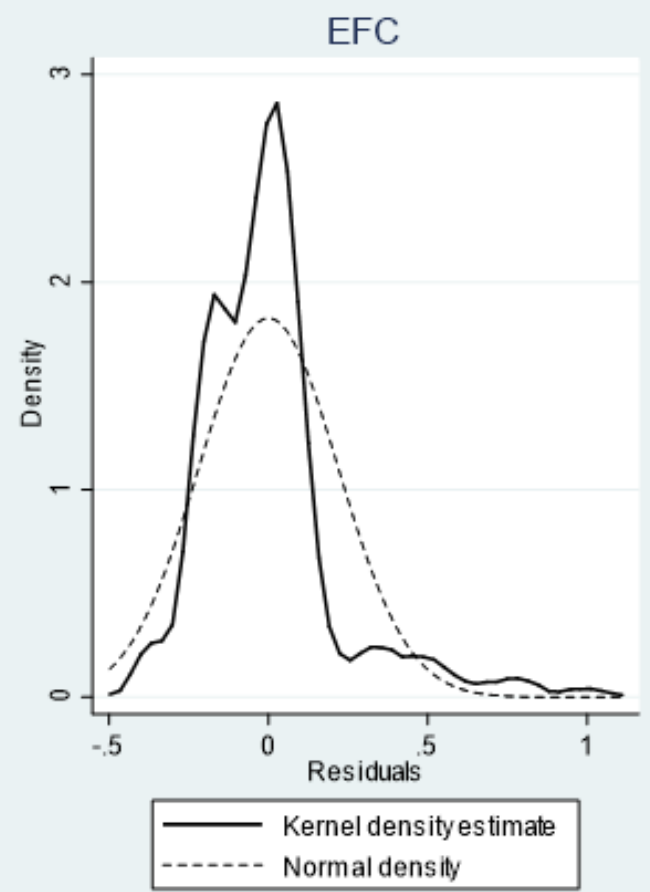

kernel $=$ epanechnikov, bandwitth $=0.0375$

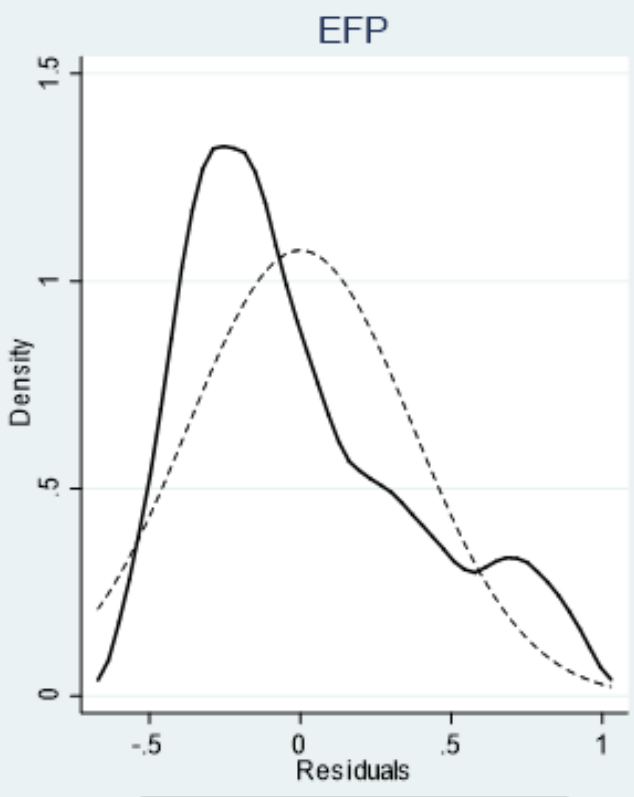

Kernel density estimate ------ Normal density

kernel $=$ epanechnikov, bandwidth $=0.0909$

\section{Figure 3}

Kernel density estimated and normal density Note: Variables are in natural logarithm. 

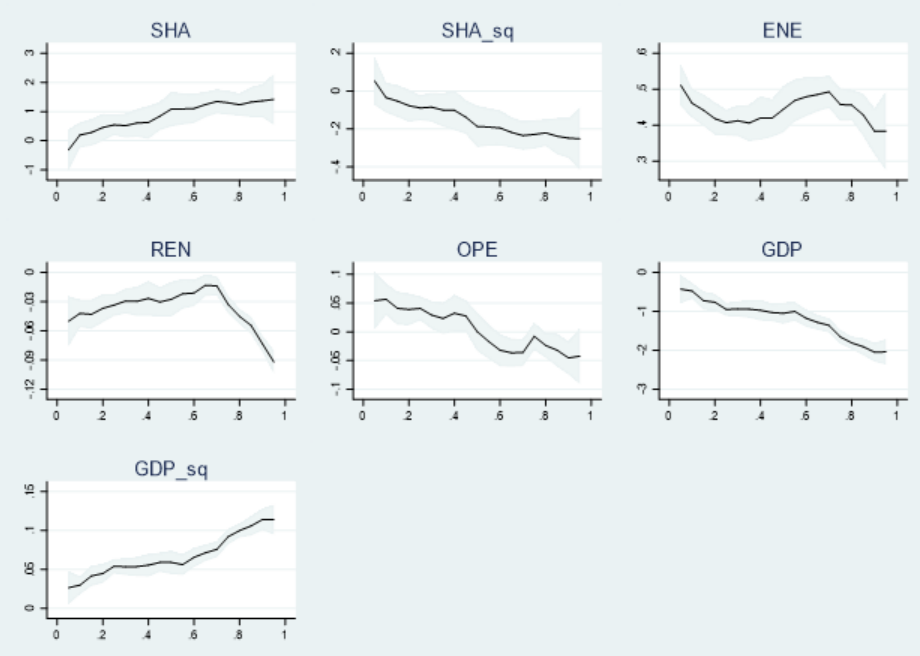

(a)
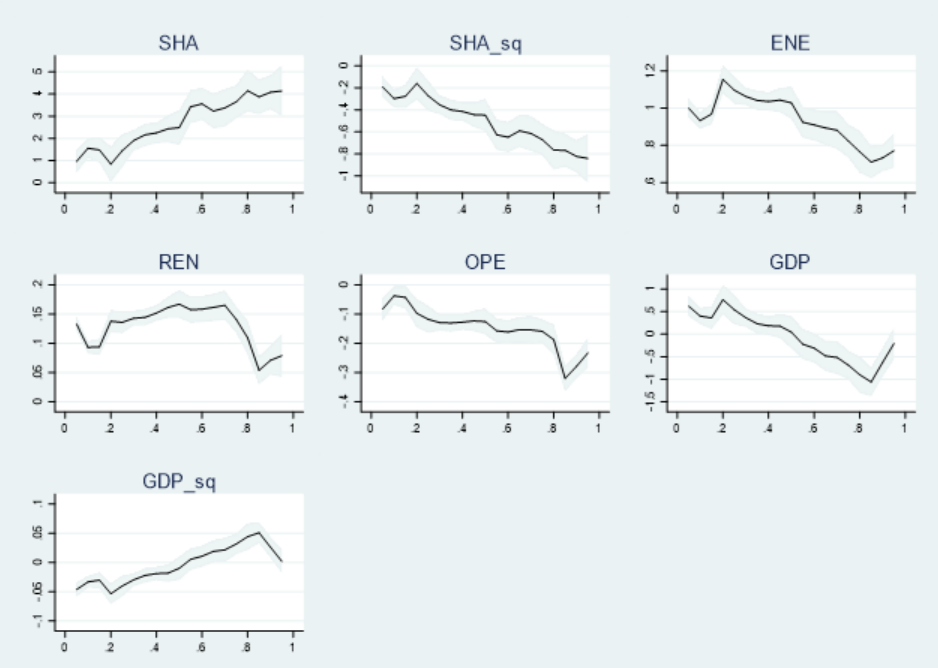

(b)

\section{Figure 4}

Canay (2011) estimates with 95\% confidence intervals Panel A. Consumption ecological footprint Panel B. Production ecological footprint 